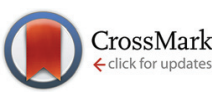

Cite this: Org. Biomol. Chem., 2016, 14, 10894

Received 7th October 2016

Accepted 27th October 2016

DOI: $10.1039 / c 6 o b 02191 c$

www.rsc.org/obc

\section{Photochemical formation of quinone methides from peptides containing modified tyrosine $\uparrow$}

\author{
Antonija Husak, ${ }^{a}$ Benjamin P. Noichl, ${ }^{b}$ Tatjana Šumanovac Ramljak, ${ }^{a}$ \\ Margareta Sohora, ${ }^{a}$ Đani Škalamera, ${ }^{a}$ Nediljko Budiša ${ }^{b}$ and Nikola Basarić*a
}

\section{Introduction}

Quinone methides (QMs) are reactive intermediates in the chemistry and photochemistry of phenols that have received significant scientific attention over the past twenty years. ${ }^{1,2}$ Interest in their chemistry has been initiated due to their applications in synthesis, ${ }^{3,4}$ as well as their biological activity. $^{5-7}$ To date, the biological effects of QMs have been connected to their reactivity with nucleobases ${ }^{8-10}$ and DNA. ${ }^{11-14}$ More importantly, some antineoplastic antibiotics base their action on the metabolic formation of QMs that cross-link DNA. ${ }^{15,16}$ A significant endeavor in elucidating the reactivity of QMs with DNA has been undertaken by Rokita et al., ${ }^{1,16}$ who demonstrated reversible alkylation of DNA by QMs. ${ }^{9}$ They have shown that QMs act as "immortal” species that are capable of forming thermodynamically most stable

\footnotetext{
${ }^{a}$ Department of Organic Chemistry and Biochemistry, Ruđer Bošković Institute, Bijenička cesta 54, 10000 Zagreb, Croatia.E-mail: nbasaric@irb.hr; Tel: +38514561 141; Fax: +38514680195

${ }^{b}$ Institute for Chemistry, Technical University Berlin, Müller-Breslau-Str. 10, 10623 Berlin, Germany

$\dagger$ Electronic supplementary information (ESI) available: Synthetic procedures for the preparation of known precursors, fluorescence spectra of 2 and 3, LFP data, and ${ }^{1} \mathrm{H}$ and ${ }^{13} \mathrm{C}$ NMR spectra. See DOI: 10.1039/c6ob02191c
}

DNA cross-adducts. ${ }^{17-19}$ However, it has also been demonstrated that QMs react with amino acids ${ }^{20,21}$ and proteins. ${ }^{22}$ Thus, we have recently shown that the antiproliferative activity of QMs formed in the phototautomerization of hydroxyphenylanthracenes is due to the reaction with intracellular proteins, rather than with DNA. ${ }^{23}$

Formation of QMs often requires harsh conditions such as elevated temperature, ${ }^{24,25}$ or the use of biologically inacceptable oxidants ${ }^{26}$ or $\mathrm{F}^{-} .^{13}$ On the contrary, photochemical reactions require mild conditions which allow for the generation of QMs in living cells. ${ }^{7,27}$ Two main photochemical reactions for the formation of QMs are dehydration of hydroxymethyl substituted phenols ${ }^{28,29}$ and deamination of aminomethyl ${ }^{30}$ or ammoniummethylphenols. ${ }^{21,31}$ Photodeamination can also be initiated by an intramolecular photoinduced electron transfer reaction with naphthalene diimide as a photooxidizing agent. $^{32}$ Freccero et al. have used photodeamination of Mannich salts for the investigation of biological activity of QMs, ${ }^{33,34}$ and the ability of QM derivatives to selectively target guanine quadruplexes has been demonstrated. ${ }^{35-37}$ We have investigated the dependence of the photodeamination efficiency on $\mathrm{pH}$ in aqueous media and have shown that this reaction is the most efficient one for zwitterionic prototropic forms at $8.5<\mathrm{pH}<11.1 .^{38}$ Furthermore, Freccero et al. focused their study on the structure of QM precursors resulting 
in high efficiency of deamination or high intersystem crossing yields and population of triplets. ${ }^{39}$
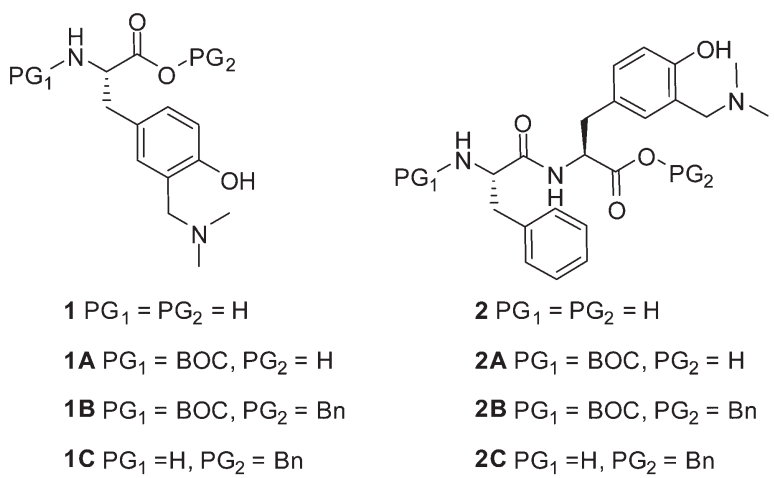

$2 P G_{1}=P G_{2}=H$

2A PG $1=B O C, P G_{2}=H$

2BPG $=B O C, P G_{2}=B n$

2C $\mathrm{PG}_{1}=\mathrm{H}, \mathrm{PG}_{2}=\mathrm{Bn}$

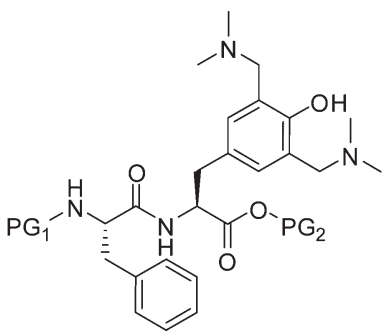

$3 \mathrm{PG}_{1}=\mathrm{PG}_{2}=\mathrm{H}$

$3 A P_{1}=B O C, P G_{2}=H$

3B $P G_{1}=B O C, P G_{2}=B n$

$3 \mathrm{C} P \mathrm{PG}_{1}=\mathrm{H}, \mathrm{PG}_{2}=\mathrm{Bn}$
Herein we report the synthesis and photochemical reactivity of Mannich derivatives of tyrosine 1, dipeptide derivatives PheTyr 2 and 3. Photochemical reactivity was investigated by performing preparative irradiation in $\mathrm{CH}_{3} \mathrm{OH}$ as a nucleophilic solvent where photomethanolysis takes place, whereas QMs were detected by laser flash photolysis (LFP). Furthermore, we have prepared a tripeptide containing 1 and incorporated it in a 20-residue mini-protein, the Trp-Cage analogue TC10b. ${ }^{40}$ It is a synthetic mini-protein, derived from exendin- $4,{ }^{41}$ with a known and defined secondary structure, widely used to study folding dynamics and their pathways. ${ }^{41,42}$ Recently, the TC5b analogue was used for the incorporation of non-canonical fluorescent amino acids into the core of the tryptophan cage forming motif ( $\operatorname{Trp}^{6}$ and Pro $\left.{ }^{17-19}\right)^{43}$ and from the development of this system, TC10b was found to be a more suitable analogue of Trp-Cage for the current experiments reported here, showing that the QM precursor can be imbedded into proteins whilst retaining its photochemical reactivity. QMs formed in the photochemical reactions initiate alkylation of proteins. Therefore, incorporation of the photoswitchable units in proteins can have numerous applications in organic synthesis, materials science, biology and medicine.

\section{Results and discussion}

\section{Synthesis}

QM precursor, a derivative of tyrosine 1B was synthesized in the Mannich reaction from BOC-Tyr-OBn and Eschenmoser's salt (Scheme 1), according to the procedure in the literature precedent. ${ }^{38}$ BOC-Tyr-OBn was prepared according to the usual procedures for the introduction of protective groups. ${ }^{44}$ Unnatural amino acid 1B was deprotected at the N-site by the use of trifluoroacetic acid (TFA) to yield 1C, or at the C-terminus by hydrogenolysis to furnish 1A. Both deprotections were conducted in high yields without any interference or change of the aminomethylphenol moiety.

The synthesis of dipeptides with the incorporated QM precursor was conducted in two ways, by introduction of the functional group in the Mannich reaction after peptide coupling,
Dipeptide BOC-Phe-Tyr-OH was synthesized from BOC-Phe$\mathrm{OH}$ by the use of $N$-hydroxysuccinimide (NHS) and 1-ethyl3-(3-dimethylaminopropyl)carbodiimide (EDC) activation. $^{45}$ Protected dipeptide BOC-Phe-Tyr-OBn was transformed into QM precursor dipeptide 2B in the Mannich reaction with Eschenmoser's salt where only one aminomethyl group was introduced. Preparation of the Mannich reagent in situ with an excess of dimethylamine and formaldehyde allowed for the introduction of two aminomethyl groups, yielding 3B. Thus, we have demonstrated that tyrosine in a peptide can be transformed into a QM precursor in the Mannich reaction. However, peptides cannot contain amino acids that react with electrophiles (e.g. tryptophan).

The other synthetic protocol for the preparation of peptide 2B was the coupling of activated BOC-Phe-OH with the $\mathrm{N}$-free site of QM precursor 1C (Scheme 2). Peptide coupling by the use of NHS and EDC activation ${ }^{45}$ was conducted, giving the desired QM precursor in a moderate yield (57\%).<smiles>N[C@@H](Cc1ccc(O)cc1)C(=O)O</smiles>

$\mathrm{H}-\mathrm{Tyr}-\mathrm{OH}$

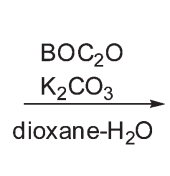

$\mathrm{PhCH}_{2} \mathrm{Br}$ $\mathrm{NaHCO}_{3}$<smiles>CC(C)(C)OC(=O)N[C@@H](Cc1ccc(O)cc1)C(=O)O</smiles>
Boc-Tyr-OH dioxane-DMF hioxane-DMF<smiles>CC(C)(C)OC(=O)N[C@@H](Cc1ccc(O)cc1)C(=O)OCc1ccccc1</smiles>

Boc-Tyr-OBn
TFA

$\mathrm{H}_{2}, \mathrm{Pd} / \mathrm{C}$

$1 B P G_{1}=B O C, P G_{2}=B n$

$1 A P G_{1}=B O C, P G_{2}=H$ 


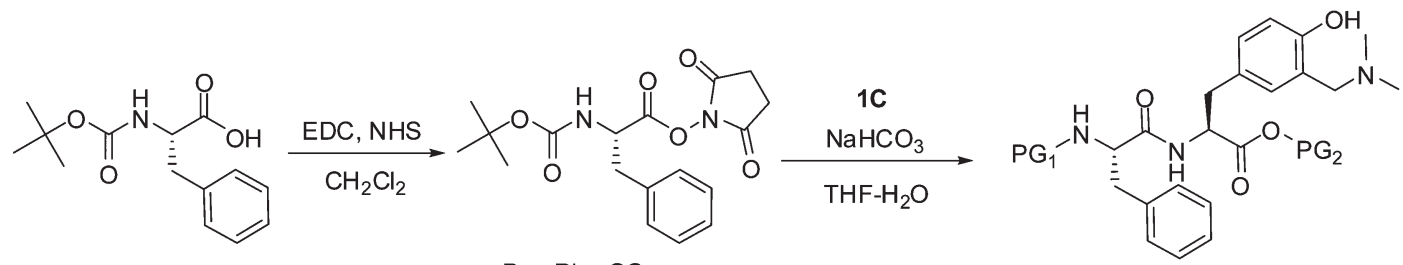
Boc-Phe-OH

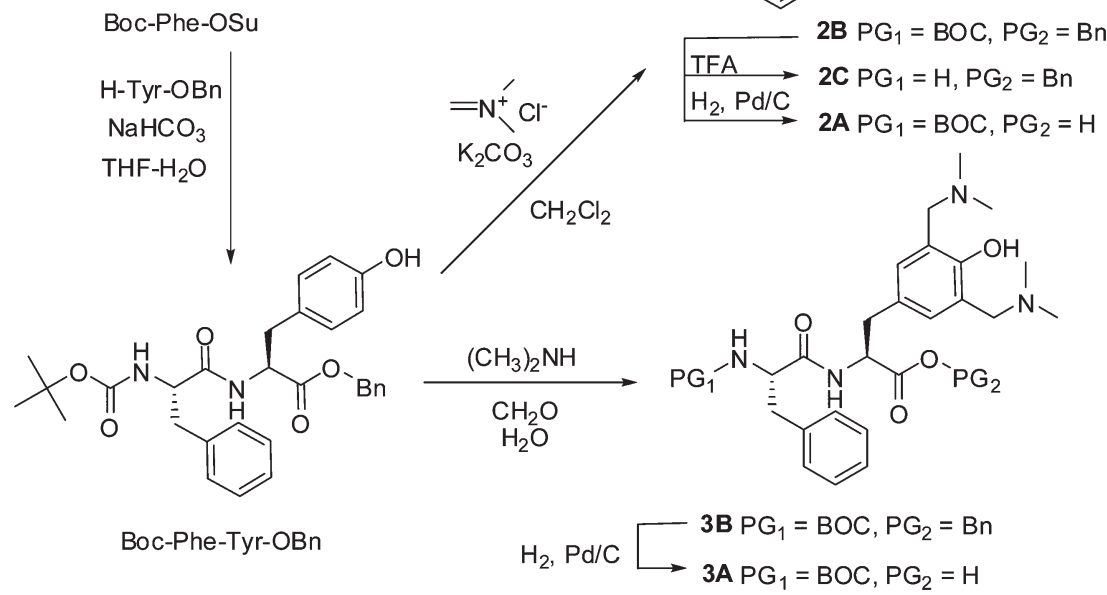

Scheme 2

Consequently, we have demonstrated that QM precursor $1 \mathrm{C}$ can be used as a building block in peptide synthesis. Attempts to perform activation of the carboxylic group in $\mathbf{1 A}$ and couple it with H-Phe-OBn failed by the use of NHS and EDC activation $^{47}$ or by the $N, N, N^{\prime}, N^{\prime}$-tetramethyl-O-(1H-benzotriazol-1yl)uronium hexafluorophosphate (HBTU) and 1-hydroxybenzotriazole (HOBT) activation protocol. ${ }^{46}$ Nevertheless, dipeptides 2 and 3 can be easily deprotected, and in principle, used in further synthesis of more complex molecules.

The synthesis of more complex peptides with incorporated modified tyrosine was accomplished by a combination of solid and liquid phase peptide synthesis (LPPS \& SPPS). Tripeptide 4 was synthesized via LPPS deploying the alternating activation of the C-terminus (EDC. $\mathrm{HCl}$ and NHS, Scheme 3 ) and coupling of the unprotected amino acids Ala-OH and $\mathbf{1}$ (Scheme 3). For the latter coupling step, the required deprotection of $\mathbf{1 B}$ was accomplished in two steps, using $\mathrm{H}_{2} / \mathrm{Pd}$ in $\mathrm{EtOH}$ for the selective removal of the benzyl group, followed by $4 \mathrm{M} \mathrm{HCl}$ in dioxane to yield the desired unprotected amino acid 1 (97\%, two steps), which was used for the coupling. This approach provides the desired amino acid sequence - Asp-Ala-1- (4) in a completely protected manner, suitable for the synthesis of longer peptide chains.

The synthesis of the corresponding mini-protein was accomplished using SPPS. Therefore, the previously synthesized intermediate 5 on the solid support (see Scheme S1 in the ESI $\dagger$ ) and protected tripeptide $\mathbf{4}$ were utilized. For the intermediate 5 we have chosen the first 17 amino acids of the Trp-Cage analogue TC10b. ${ }^{40}$ In this way the TC10b analogue was obtained, bearing 1 instead of tyrosine at the position
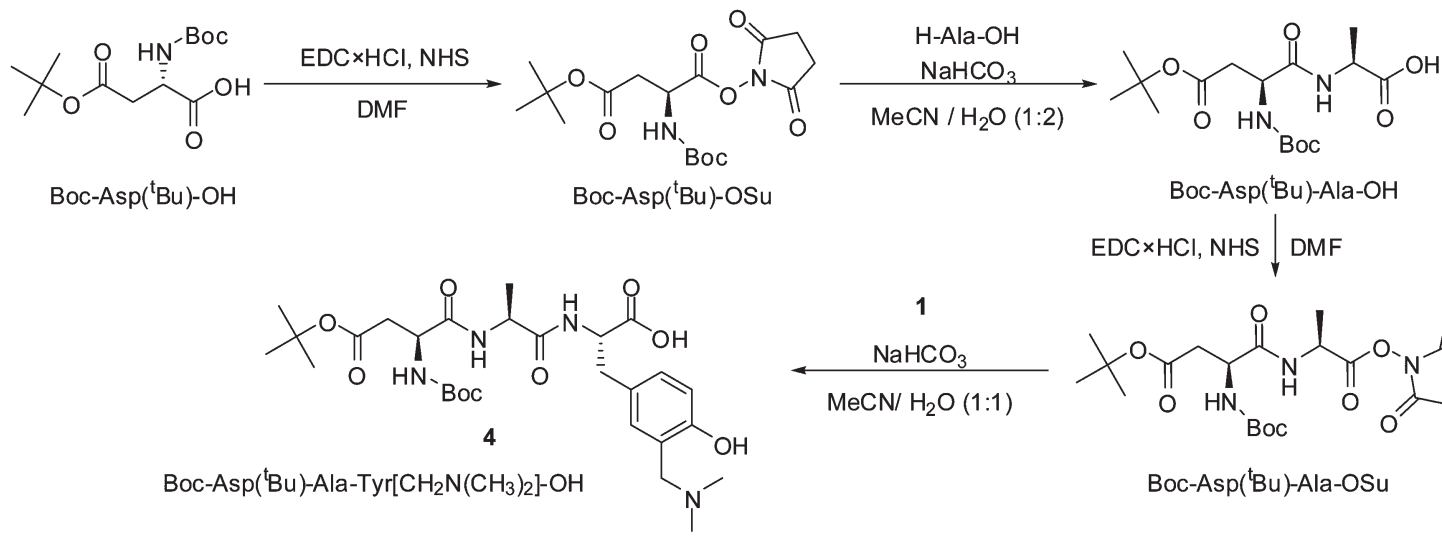

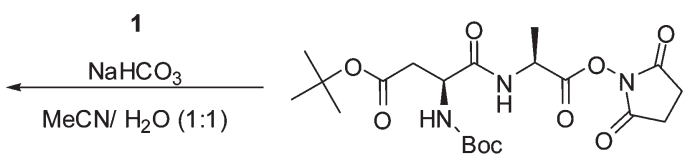

Boc-Asp('Bu)-Ala-OSu 


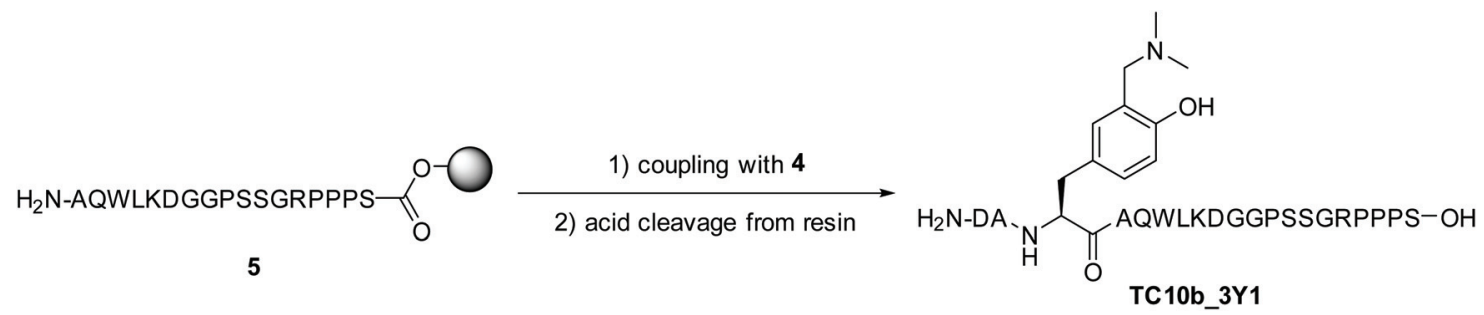

Scheme 4

3. The coupling was performed in the presence of $O$-(benzo-

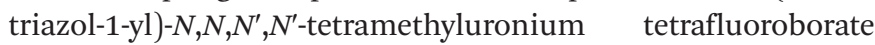
(TBTU) and $N, N$-diisopropylamine (DIPEA) for 1 hour in $N, N$ dimethylformamide (DMF), followed by an acid deprotection step, yielding the desired peptide TC10b_3Y1 (Scheme 4). The structure of the peptide was confirmed by MS (ESI-HR: $\mathrm{m} / \mathrm{z}=$ 1072.53394, calculated for $[\mathrm{M}+\mathrm{H}]^{+}:$1072.53366; $\Delta m / z=$ $0.2 \mathrm{ppm})$.

\section{Photophysical properties}

The spectral properties of QM precursors 1 are anticipated not to differ from those of the parent molecule. However, it is interesting to investigate the spectral properties of dipeptides 2 and 3 that contain two chromophores, phenylalanine, and the modified tyrosine. Their spectral and photophysical properties were investigated in $\mathrm{CH}_{3} \mathrm{CN}$ (Table 1 , for spectra see Fig. S2-S7 in the ESI†).

In the absorption spectra of dipeptides 2 and $3 \mathbf{A}$ (Fig. S2 and S5 in the ESI + ) the typical absorption band at $\approx 280 \mathrm{~nm}$ was observed corresponding to the $S_{0} \rightarrow S_{1}$ absorption of the tyrosine moiety. In the emission spectra recorded in $\mathrm{CH}_{3} \mathrm{CN}$ (Fig. S3 and S6 in the ESI $\dagger$ ), the typical dual fluorescence was observed with one main band at 305-315 nm, and a shoulder at $370 \mathrm{~nm}$ for 2 , and $430 \mathrm{~nm}$ for $\mathbf{3 A}$. This dual fluorescence is due to the emission of phenol and phenolate. Both species are present in equilibrium in $\mathrm{S}_{0}$, but the phenolate is also formed in $\mathrm{S}_{1}$ by excited state intramolecular proton transfer (ESIPT), as seen for the Mannich derivatives of cresol. $^{38}$ Namely, upon electronic excitation, phenols exhibit enhanced acidity (unsubstituted phenol $\left.\mathrm{p} K_{\mathrm{a}}^{*}=3.6\right),{ }^{48,49}$ and the methylamine group has a role of a basic site. The appearance of the emission spectra depends on the excitation and emission wavelength, which is expected in a bichromophoric system containing Phe and Tyr. Moreover, due to the acidic and basic functionalities in the molecule, the dipeptides exhibit several prototropic forms. Therefore, fluorescence quantum yield depends on the excitation wavelength, and the decay of fluorescence cannot be fit to single exponential function. Due to the complexity of the chromophoric system, no attempt was made to assign the fluorescence decay components. In Table 1 , only an estimate for the fluorescence quantum yield $\left(\Phi_{\mathrm{F}}\right)$ is reported, measured by the use of anisole in cyclohexane $\left(\Phi_{\mathrm{F}}=0.29\right) .{ }^{47}$ Generally, $\Phi_{\mathrm{F}}$ values are very low, probably due to the relatively efficient deactivation from $\mathrm{S}_{1}$ by photodeamination giving $\mathrm{QMs}^{38}$ Addition of $\mathrm{H}_{2} \mathrm{O}$ to the $\mathrm{CH}_{3} \mathrm{CN}$ solution until a concentration of $4 \mathrm{M}$ was reached quenched the fluorescence to about 2-3 times, but further additions did not result in additional quenching. Due to very weak fluorescence in the aqueous solution and complexity due to several $\mathrm{pH}$-dependant prototropic forms, ${ }^{38}$ we constrained our measurements to $\mathrm{CH}_{3} \mathrm{CN}$ solution only.

\section{Photochemistry}

Photodeamination of aminomethylphenols in aqueous $\mathrm{CH}_{3} \mathrm{OH}$ leads to photomethanolysis products via QM intermediates. ${ }^{32,38,50}$ To demonstrate that photomethanolysis of modified tyrosine $\mathbf{1}$ and dipeptides $\mathbf{2}$ and $\mathbf{3}$ also takes place, we performed preparative irradiation of $\mathbf{1 B}, \mathbf{2 B}$ and $3 \mathbf{B}$. Fully protected compounds (bearing BOC and Bn) were chosen for preparative irradiation to make the product isolation easier. The irradiation experiments were conducted by irradiating $\mathrm{CH}_{3} \mathrm{OH}$ solutions at $300 \mathrm{~nm}$ and by analyzing the composition

Table 1 Spectral and photophysical properties of dipeptides in $\mathrm{CH}_{3} \mathrm{CN}$

\begin{tabular}{|c|c|c|c|c|}
\hline & $\lambda_{\mathrm{abs}} / \mathrm{nm}\left(\varepsilon / \mathrm{dm}^{3} \mathrm{~mol}^{-1} \mathrm{~cm}^{-1}\right)^{a}$ & $\lambda_{\mathrm{em}}{ }^{b} / \mathrm{nm}$ & $\Phi_{\mathrm{F}}^{c}$ & $\tau^{d} / \mathrm{ns}$ \\
\hline $3 \mathbf{A}$ & $286(1700)$ & 315 & $\approx 0.007$ & $\begin{aligned} 0.22 & \pm 0.04(0.26) \\
0.75 & \pm 0.03(0.54) \\
6.0 & \pm 0.1(0.12)\end{aligned}$ \\
\hline
\end{tabular}

\footnotetext{
${ }^{a}$ Maximum in the absorption spectrum and molar absorption coefficient in the brackets. ${ }^{b}$ Maximum in the emission spectrum. ${ }^{c}$ Approximate quantum yield of fluorescence measured by the use of anisole in cyclohexane $\left(\Phi_{\mathrm{F}}=0.29\right)^{47}$ as a reference upon excitation at $260 \mathrm{~nm}$. ${ }^{d}$ Decay of fluorescence at $310 \mathrm{~nm}$ measured by time-correlated single photon counting (SPC), pre-exponential factors are given in brackets.
} 
of the solutions by HPLC. After the irradiation, the photoproducts were isolated by preparative TLC and characterized by NMR spectroscopy. Methanolysis of $\mathbf{1 B}$ until the conversion of $44 \%$ gave methyl ether 6 , with the isolated yield of $28 \%$ (eqn (1)).

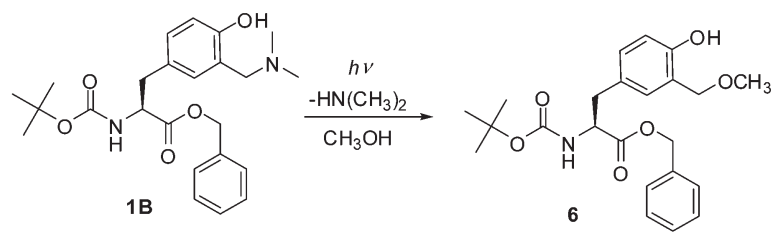

Similarly, irradiation of dipeptide $\mathbf{2 B}$ until the conversion of $63 \%$ was achieved gave cleanly only methyl ether 7 (isolated yield $21 \%$, eqn (2)).

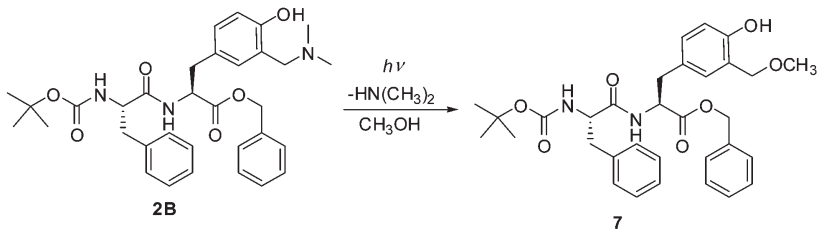

On the other hand, irradiation of $\mathbf{3 B}$ gave a mixture of products 8 and $\mathbf{9}$ whose ratio depended on the irradiation time (eqn (3)). Thus, after irradiating for $30 \mathrm{~min}$, the ratio of $\mathbf{8 : 9}$ was $1: 1$. After prolonged irradiation until the conversion of $68 \%, 9$ was isolated in $21 \%$ yield. Similarly, after irradiation of peptide $3 \mathbf{A}$ until the conversion of $40 \%$ dimethoxy product $\mathbf{1 0}$ was isolated in 5\% yield (eqn (4)).
Table 2 Quantum yields of photomethanolysis $\left(\Phi_{\mathrm{R}}\right)^{a}$

\begin{tabular}{lr}
\hline & \multicolumn{1}{c}{$\Phi_{\mathrm{R}}$} \\
\hline 1A & $0.17 \pm 0.03$ \\
1B & $0.17 \pm 0.04$ \\
1C·TFA & $0.23 \pm 0.04$ \\
2B & $0.28 \pm 0.04$ \\
2C & $0.32 \pm 0.05$ \\
3A & $0.07 \pm 0.02$ \\
& \\
${ }^{a}$ Irradiation experiments were performed in $\mathrm{CH}_{3} \mathrm{OH}$ at $254 \mathrm{~nm}$. \\
Measurement was performed in duplicate by the use of two actin- \\
ometers, $\mathrm{KI} / \mathrm{KIO}_{3}\left(\Phi_{254}=0.74\right)^{47,51}$ and 2-hydroxymethylphenol $\left(\Phi_{254}=\right.$ \\
${ }^{0.23) .}{ }^{28}$
\end{tabular}

piled in Table 2. The efficiency was measured for all Mannich derivatives 1 to demonstrate that the protective groups on tyrosine do not affect the photomethanolysis reaction. The corresponding photoproducts from 1, 1A and 1C were detected by HPLC, but product isolation was conducted only for the fully protected isomer 1B. Moreover, the $\Phi_{\mathrm{R}}$ was measured for the dipeptide bearing one or two aminomethyl groups.

The values in Table 2 indicate similar photochemical reaction efficiencies of tyrosine QM precursors 1A-1C, irrespective of the protective groups used. Moreover, QM precursors remain photochemically reactive in dipeptides $\mathbf{2 B}$ and $\mathbf{2 C}$ where photomethanolysis takes place with similar efficiencies to those of derivatives 1 . Dipeptides 2 contain two chromophores, Phe and Tyr both of which can be excited at $254 \mathrm{~nm}$. Similar photomethanolysis efficiency for 2 suggests that

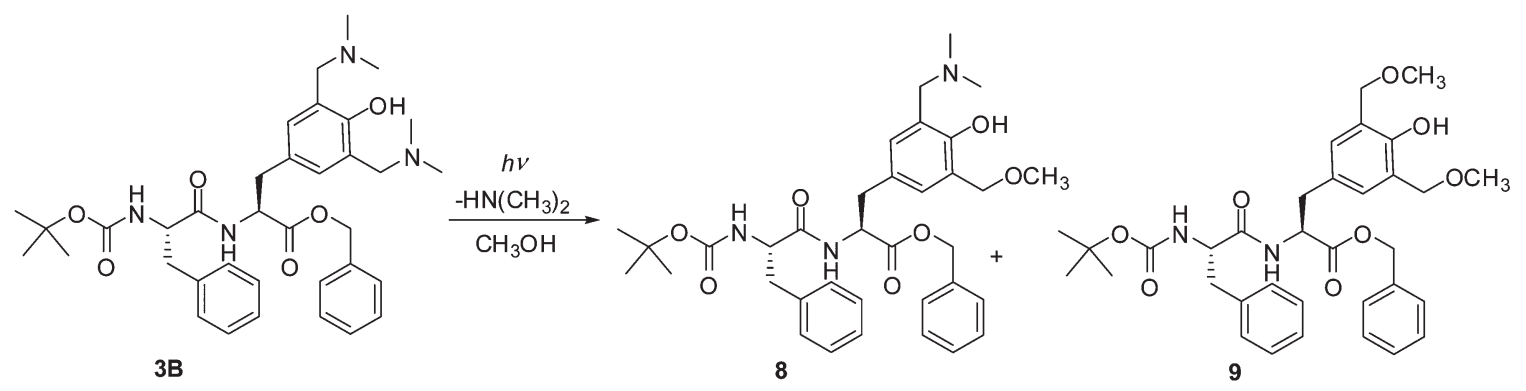

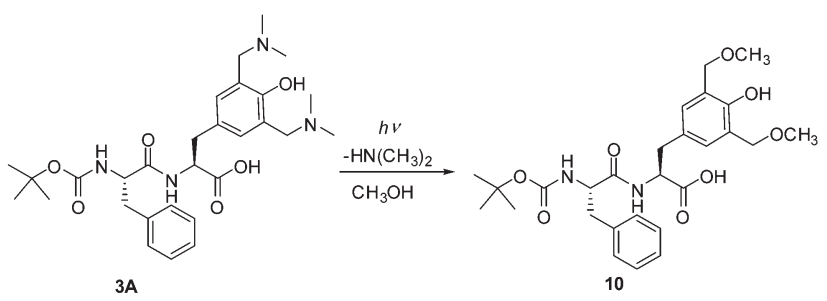

The efficiency of the photomethanolysis reaction $\left(\Phi_{\mathrm{R}}\right)$ was measured by the use of a primary actinometer, $\mathrm{KI} / \mathrm{KIO}_{3} \Phi_{254}=$ $0.74),{ }^{47,51}$ and a secondary actinometer, photomethanolysis of 2-hydroxymethylphenol $\left(\Phi_{254}=0.23\right){ }^{28}$ The values are com- energy transfer from Phe to Tyr takes place leading to photoelimination, regardless of which chromophore was initially excited.

Photochemical reactivity was also tested with the protected tripeptide 4 in the presence of benzyl mercaptan. After the irradiation of the reaction solution for $20 \mathrm{~min}$ at $254 \mathrm{~nm}$, the completely oxidized product was detected with the conversion of $23 \%$. Only a minor fraction of the products of photoreaction was identified to be the non-oxidized product (see the ESI $\dagger$ ). These results indicate that tripeptide also undergoes photodeamination giving QMs that can be trapped with nucleophiles. Irradiation of the mini-protein TC10b_3Y1 was performed in $\mathrm{CH}_{3} \mathrm{OD}$ where the photomethanolysis reaction is anticipated. After one hour irradiation at $254 \mathrm{~nm}$, MS analysis indicated its conversion to the corresponding methyl ether, 
which clearly demonstrates that photoreaction of the QM precursor is feasible, and shows this reaction's applicability to protein systems.

\section{Laser flash photolysis (LFP)}

To detect QM intermediates in the photochemistry of dipeptides 2 and 3, LFP was used. The samples were excited with a $\mathrm{Nd}$ :YAG laser at $266 \mathrm{~nm}$. The measurements were performed in $\mathrm{N}_{2}$ and $\mathrm{O}_{2}$-purged $\mathrm{CH}_{3} \mathrm{CN}$ solution, where $\mathrm{O}_{2}$ is expected to quench triplets and radicals, but not QMs. Moreover, the spectra and decay kinetics were measured in $\mathrm{CH}_{3} \mathrm{CN}$ and $\mathrm{CH}_{3} \mathrm{CN}-\mathrm{H}_{2} \mathrm{O}(1: 1)$ where the difference is expected due to ESPT pathways, ${ }^{52-55}$ and different reactivities of QMs in aprotic and protic solution (for the transient absorption spectra see Fig. S8-S16 in the ESI $\dagger$ ). ${ }^{38,56-60}$

Dipeptide 2 is not well soluble in $\mathrm{CH}_{3} \mathrm{CN}$. However, in neat $\mathrm{CH}_{3} \mathrm{CN}$ solution a transient was detected with a maximum at $390 \mathrm{~nm}$ (Fig. S8 in the ESI $\dagger$ ), tentatively assigned to 2-QM based on the comparison with the previously published spectra of $o$-QM derivatives. ${ }^{38,61}$ Due to a long lifetime of the transient and its low intensity, decay kinetics in $\mathrm{CH}_{3} \mathrm{CN}$ was not investigated. Spectra of better quality were obtained in $\mathrm{CH}_{3} \mathrm{CN}-\mathrm{H}_{2} \mathrm{O}(1: 1)$ solution where the compound is more soluble (Fig. 1). The transient assigned to 2-QM was detected with a maximum at $400 \mathrm{~nm}$. It was formed within a laser pulse and it decayed to the baseline with unimolecular kinetics and

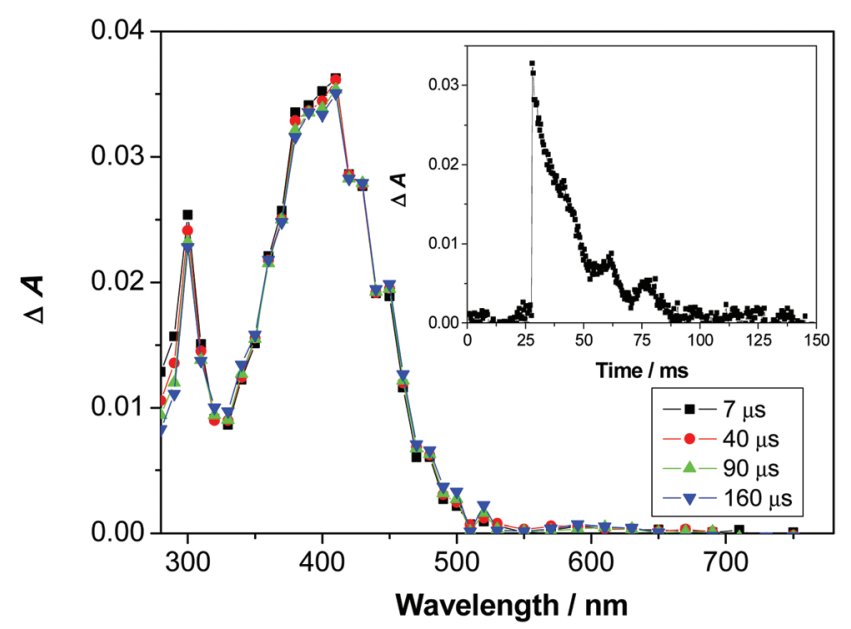

Fig. 1 Transient absorption spectra of $\mathrm{O}_{2}$-purged $\mathrm{CH}_{3} \mathrm{CN}-\mathrm{H}_{2} \mathrm{O}(1: 1)$ solution of 2. Inset: decay of transient absorbance at $400 \mathrm{~nm}$. lifetime of $20 \pm 2 \mathrm{~ms}$ (Table 3 ). To verify its assignment a quenching study was performed with ethanolamine (EtAm) and $\mathrm{NaN}_{3}$, ubiquitous QM quenchers, ${ }^{38,60,62-66}$ as well as with ethyl vinyl ether (EVE) that reacts with QMs in the Diels-Alder reaction (Fig. S10-S12 in the ESI $\dagger$ ). ${ }^{67}$ The measured quenching constants (Table 3 ) are in agreement with the expected reactivity of QM with nucleophiles. ${ }^{38}$<smiles>C=C1C=C(C[C@H](NC(=O)[C@H]([NH3+])Cc2ccccc2)C(=O)[O-])C=CC1=O</smiles>

In the $\mathrm{CH}_{3} \mathrm{CN}$ solution of $\mathbf{3 A}$, a transient was detected with a maximum at $400 \mathrm{~nm}$ (Fig. S9 and S13 in the ESI $\dagger$ ). The transient was formed within the laser pulse and decayed to the baseline with unimolecular kinetics and a lifetime of $110 \pm 10 \mu \mathrm{s}$. The transient was not affected with $\mathrm{O}_{2}$, but it was quenched with EtAm (Table 3), so it was assigned to 3A-QM. The same transient corresponding to $\mathbf{3 A - Q M}$ was also detected in aqueous solution (Fig. S14 $\dagger$ ), but its decay was slower $(\tau=$ $13 \mathrm{~ms}$ ). Although this finding seemed counterintuitive at first, the same behavior was observed with bifunctional cresol derivatives. ${ }^{38}$ Most probably, the carboxylic acid from the C-terminus of the peptide in $\mathrm{CH}_{3} \mathrm{CN}$ acts as an acidic catalyst, shortening the QM lifetime, whereas in aqueous solution at pH 7, this carboxylic acid is deprotonated. Quenching of the transient in aqueous solution was performed with EtAm and EVE, revealing the typical reactivity of QM and proving that the transient assignment was correct.

\section{Conclusions}

We synthesized new QM precursors, tyrosine derivatives 1, and incorporated them in the dipeptides 2. Moreover, we have demonstrated that QM precursors can be made from peptides containing tyrosine in the Mannich reaction, or by using modified tyrosine $\mathbf{1}$ as a building block in the usual peptide synthesis. Although peptide derivatives have several acidic and

Table 3 Data obtained by LFP for 2 and 3A

\begin{tabular}{|c|c|c|c|c|c|}
\hline Transient & $\tau_{\mathrm{CH}_{3} \mathrm{CN}}{ }^{a} / \mathrm{ms}$ & $\tau_{\mathrm{CH}_{3} \mathrm{CN}-\mathrm{H}_{2} \mathrm{O}}{ }^{b} / \mathrm{ms}$ & $k_{\mathrm{q}}(\mathrm{EtAm})^{c} / \mathrm{M}^{-1} \mathrm{~s}^{-1}$ & $k_{\mathrm{q}}\left(\mathrm{NaN}_{3}\right)^{d} / \mathrm{M}^{-1} \mathrm{~s}^{-1}$ & $k_{\mathrm{q}}(\mathrm{EVE})^{e} / \mathrm{M}^{-1} \mathrm{~s}^{-1}$ \\
\hline 2-QM & - & $20 \pm 2$ & $2.3 \times 10^{5}$ & $1.1 \times 10^{7}$ & $9.9 \times 10^{2}$ \\
\hline 3A-QM & $0.11 \pm 0.01$ & $13 \pm 3$ & $2.3 \times 10^{5} f^{9.9} \times 10^{4}$ & - & $5.8 \times 10^{3}$ \\
\hline
\end{tabular}

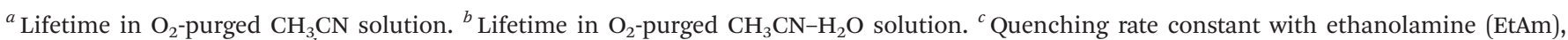

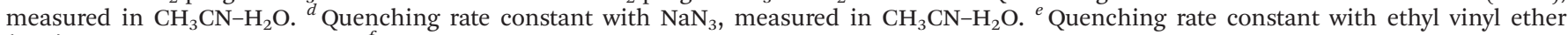
(EVE), measured in $\mathrm{CH}_{3} \mathrm{CN}-\mathrm{H}_{2} \mathrm{O} .{ }^{f}$ Measured in $\mathrm{CH}_{3} \mathrm{CN}$. 
basic sites, and their photophysical properties are complex, photochemical reactivity of modified tyrosine and dipeptides in the deamination reaction is not affected by the peptide backbone. Moreover, reactivity of QM-dipeptides that are formed in the photodeamination reactions is not altered by the peptide. Consequently, photochemical reactions of 2, 3 and TC10b_3Y1 show a proof of principle that the QM precursor can be introduced into the peptide and used as a photochemical switch to enable the interaction and alkylation of peptides with other molecules of interest, which can have a tremendous impact in chemistry and biology.

\section{Experimental}

\section{General}

${ }^{1} \mathrm{H}$ and ${ }^{13} \mathrm{C}$ NMR spectra were recorded at 300,500 or $600 \mathrm{MHz}$ at rt, using TMS as a reference and chemical shifts were reported in ppm. Melting points were determined using Mikroheiztisch apparatus and were not corrected. HRMS were obtained on a MALDI TOF/TOF instrument. ESI-MS were obtained on a LTQ Orbitrap instrument. Irradiation experiments were performed in a reactor equipped with 11 lamps with the output at $300 \mathrm{~nm}$ or a reactor equipped with 8 lamps at 254 or $300 \mathrm{~nm}(1$ lamp $8 \mathrm{~W})$. During irradiation, the irradiated solutions were continuously purged with argon and cooled by a tap-water finger-condenser. Solvents for irradiation were of HPLC purity. Chemicals were purchased from the usual commercial sources and were used as received. Solvents for chromatographic separations were used as they were delivered by the supplier (p.a. or HPLC grade) or purified by distillation $\left(\mathrm{CH}_{2} \mathrm{Cl}_{2}\right)$. Preparations of the known compounds, L-BOC-Tyr $(\mathrm{OH})-\mathrm{OH},{ }^{68}$ L-BOC-Tyr $(\mathrm{OH})-\mathrm{OBn},{ }^{44}$ L-BOC-Phe-OSu, $^{45}$ and $\mathrm{L}-\mathrm{BOC}-\mathrm{Phe}-\mathrm{Tyr}(\mathrm{OH})-\mathrm{OH},{ }^{69,70}$ are given in the ESI. $\dagger$

\section{BOC-Tyr $\left[\mathrm{CH}_{2} \mathrm{~N}\left(\mathrm{CH}_{3}\right)_{2}\right]$-OBn (1B)}

A flask was charged with BOC-Tyr-OBn (1.11 g, $3.0 \mathrm{mmol})$ and $\mathrm{CH}_{2} \mathrm{Cl}_{2}(150 \mathrm{~mL})$ was added. To this solution, $\mathrm{K}_{2} \mathrm{CO}_{3}(0.21 \mathrm{~g}$, $1.5 \mathrm{mmol})$ and Eschenmoser's salt $(0.28 \mathrm{~g}, 3.0 \mathrm{mmol})$ were added and the reaction mixture was stirred at $\mathrm{rt}$ for 5 days. When the reaction was completed, $0.5 \mathrm{M} \mathrm{HCl}(100 \mathrm{~mL})$ was added, and the product was extracted with ethyl acetate $(3 \times 100 \mathrm{~mL})$. The solvent was removed on a rotary evaporator to afford an oily product. The product was purified by column chromatography on aluminium oxide (II-III) using $0 \rightarrow 5 \%$ $\mathrm{CH}_{3} \mathrm{OH}$ in $\mathrm{CH}_{2} \mathrm{Cl}_{2}$ as the eluent to afford the pure product $(0.72 \mathrm{~g}, 56 \%)$ in the form of colorless crystals.

Colorless crystals, mp $85-87{ }^{\circ} \mathrm{C} ;{ }^{1} \mathrm{H}$ NMR $\left(\mathrm{CD}_{3} \mathrm{OD}\right.$, $300 \mathrm{MHz}) \delta / \mathrm{ppm}: 7.35-7.22(\mathrm{~m}, 5 \mathrm{H}), 6.91$ (dd, $J=1.6,8.0 \mathrm{~Hz}$, $1 \mathrm{H}), 6.84(\mathrm{~d}, J=1.6 \mathrm{~Hz}, 1 \mathrm{H}), 6.64(\mathrm{~d}, J=8.0 \mathrm{~Hz}, 1 \mathrm{H}), 5.12(\mathrm{~d}, J=$ $12.0 \mathrm{~Hz}, 1 \mathrm{H}), 5.06$ (d, $J=12.0 \mathrm{~Hz}, 1 \mathrm{H}), 4.37-4.23(\mathrm{~m}, 1 \mathrm{H}), 3.53$ (s, 2H), 2.96 (dd, $J=6.4,13.6 \mathrm{~Hz}, 1 \mathrm{H}), 2.84$ (dd, $J=8.0,13.6$ $\mathrm{Hz}, 1 \mathrm{H}), 2.26(\mathrm{~s}, 6 \mathrm{H}), 1.38(\mathrm{~s}, 9 \mathrm{H}) ;{ }^{13} \mathrm{C} \mathrm{NMR}\left(\mathrm{CD}_{3} \mathrm{OD}, 75 \mathrm{MHz}\right)$

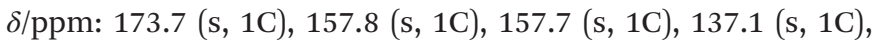
131.1 (d, 2C), 130.5 (d, 3C), 129.5 (d, 1C), 129.3 (d, 1C), 128.6 (s, 1C), 123.5 (s, 1C), $116.6(\mathrm{~d}, 1 \mathrm{C}), 80.6$ (s, 1C), 67.8 (t, 1C), $62.4(\mathrm{t}, 1 \mathrm{C}), 56.9(\mathrm{~d}, 1 \mathrm{C}), 44.7(\mathrm{q}, 2 \mathrm{C}), 37.9(\mathrm{t}, 1 \mathrm{C}), 28.6(\mathrm{q}, 3 \mathrm{C})$; HRMS (MALDI-TOF) $m / z[\mathrm{M}+\mathrm{H}]^{+}$calcd for $\mathrm{C}_{24} \mathrm{H}_{32} \mathrm{~N}_{2} \mathrm{O}_{5}$ 429.2389, found 429.2368 .

\section{BOC-Tyr $\left[\mathrm{CH}_{2} \mathrm{~N}\left(\mathrm{CH}_{3}\right)_{2}\right]-\mathrm{OH}(1 \mathrm{~A})$}

In a vessel for hydrogenation BOC-Tyr $\left[\mathrm{CH}_{2} \mathrm{~N}\left(\mathrm{CH}_{3}\right)_{2}\right]-\mathrm{OBn}$ (1B) (390 mg, $0.9 \mathrm{mmol}$ ) was dissolved in anhydrous EtOH (40 mL), and $10 \% \mathrm{Pd} / \mathrm{C}(200 \mathrm{mg})$ was added. The hydrogenation was carried out for $5 \mathrm{~h}$ at the pressure of 63 psi. The crude reaction mixture was filtered and the solvent was evaporated on a rotary evaporator. The residue was purified by column chromatography on silica gel using $20 \rightarrow 100 \% \mathrm{CH}_{3} \mathrm{OH}$ in $\mathrm{CH}_{2} \mathrm{Cl}_{2}$ to afford the pure product $(274 \mathrm{mg}, 89 \%)$ in the form of a colorless solid.

Colorless solid, mp 133-135 ${ }^{\circ} \mathrm{C} ;{ }^{1} \mathrm{H}$ NMR $\left(\mathrm{CD}_{3} \mathrm{OD}\right.$, $300 \mathrm{MHz}$ ) $\delta / \mathrm{ppm}: 7.10$ (s, 1H), 7.09 (d, $J=8.0 \mathrm{~Hz}, 1 \mathrm{H}), 6.79$ (d, $J=8.0 \mathrm{~Hz}, 1 \mathrm{H}), 4.16(\mathrm{~s}, 2 \mathrm{H}), 3.34(\mathrm{~s}, 2 \mathrm{H}), 3.03$ (dd, $J=5.0,13.5$ $\mathrm{Hz}, 1 \mathrm{H}), 2.88$ (dd, $J=6.5,13.5 \mathrm{~Hz}, 1 \mathrm{H}), 2.77$ (s, 6H), 1.39 (s, $9 \mathrm{H}) ;{ }^{13} \mathrm{C} \mathrm{NMR}\left(\mathrm{CD}_{3} \mathrm{OD}, 75 \mathrm{MHz}\right) \delta / \mathrm{ppm}: 178.3$ (s, 1C), 157.2 (s, 1C), 156.4 (s, 1C), 134.1 (d, 1C), 133.8 (d, 1C), 130.9 (s, 1C), 117.7 (s, 1C), 116.1 (d, 1C), 80.0 (s, 1C), 58.4 (t, 1C), 58.3 (d, 1C), 43.3 (q, 2C), 38.9 (t, 1C), 28.8 (q, 3C); HRMS (MALDI-TOF) $m / z[\mathrm{M}+\mathrm{H}]^{+}$calcd for $\mathrm{C}_{17} \mathrm{H}_{26} \mathrm{~N}_{2} \mathrm{O}_{5} 339.1920$, found 339.1911.

\section{TFA.H-Tyr $\left[\mathrm{CH}_{2} \mathrm{~N}\left(\mathrm{CH}_{3}\right)_{2} \cdot \mathrm{TFA}\right]-\mathrm{OBn}(1 \mathrm{C})$}

BOC-Tyr $\left[\mathrm{CH}_{2} \mathrm{~N}\left(\mathrm{CH}_{3}\right)_{2}\right]$-OBn (1B) (335 mg, $\left.0.8 \mathrm{mmol}\right)$ was dissolved in $\mathrm{CH}_{2} \mathrm{Cl}_{2}(3 \mathrm{~mL})$. TFA $/ \mathrm{CH}_{2} \mathrm{Cl}_{2}(1: 1,4 \mathrm{~mL})$ was added and the reaction mixture was stirred at $\mathrm{rt}$ for $2 \mathrm{~h}$. The solvent was removed by distillation in a vacuum to afford an oily product quantitatively.

Colorless oil; ${ }^{1} \mathrm{H}$ NMR $\left(\mathrm{CD}_{3} \mathrm{OD}, 300 \mathrm{MHz}\right) \delta / \mathrm{ppm}: 7.41-7.28$ $(\mathrm{m}, 5 \mathrm{H}), 7.14-7.09(\mathrm{~m}, 2 \mathrm{H}), 6.86(\mathrm{~d}, J=8.8 \mathrm{~Hz}, 1 \mathrm{H}), 5.26(\mathrm{~d}, J=$ $11.5 \mathrm{~Hz}, 1 \mathrm{H}), 5.20$ (d, $J=11.5 \mathrm{~Hz}, 1 \mathrm{H}), 4.31(\mathrm{dd}(\mathrm{t}), J=7.0 \mathrm{~Hz})$, $4.22(\mathrm{~d}, J=12.9 \mathrm{~Hz}, 1 \mathrm{H}), 4.13(\mathrm{~d}, J=12.9 \mathrm{~Hz}, 1 \mathrm{H}), 3.15$ (d, $J=$ $7.5 \mathrm{~Hz}, 2 \mathrm{H}), 2.79$ (d, $J=7.5 \mathrm{~Hz}, 6 \mathrm{H}) ;{ }^{13} \mathrm{C} \mathrm{NMR}\left(\mathrm{CD}_{3} \mathrm{OD}\right.$, $75 \mathrm{MHz}$ ) $\delta / \mathrm{ppm}$ : 169.9 (s, 1C), 157.5 (s, 1C), 136.2 (s, 1C), 134.4 (d, 1C), 134.0 (d, 1C), 129.9 (d, 1C), 129.8 (d, 2C), 129.7 (d, 2C), 126.6 (s, 1C), 118.0 (s, 1C), 117.0 (d, 1C), 69.3 (t, 1C), 58.2 (t, 1C), 55.2 (d, 1C), 43.2 (q, 2C), 36.5 (t, 1C); HRMS (MALDI-TOF) $\mathrm{m} / \mathrm{z}[\mathrm{M}]^{+}$calcd for $\left(\mathrm{C}_{23} \mathrm{H}_{26} \mathrm{~F}_{6} \mathrm{~N}_{2} \mathrm{O}_{7}\right)$ 556.1644, found 556.1635.

\section{BOC-Phe-Tyr $\left[\mathrm{CH}_{2} \mathrm{~N}\left(\mathrm{CH}_{3}\right)_{2}\right]$-OBn (2B)}

A flask was charged with TFA.H-Tyr $\left[\mathrm{CH}_{2} \mathrm{~N}\left(\mathrm{CH}_{3}\right)_{2} \cdot \mathrm{TFA}\right]-\mathrm{OBn}$ (1C) (594 mg, $1.8 \mathrm{mmol}$ ), $\mathrm{NaHCO}_{3}(605 \mathrm{mg}, 7.2 \mathrm{mmol}$ ) and THF- $\mathrm{H}_{2} \mathrm{O}(1: 1,24 \mathrm{~mL})$. To the mixture, a solution of succinimide-activated phenylalanine $(732 \mathrm{mg}, 2.0 \mathrm{mmol})$ in THF $(14 \mathrm{~mL})$ was added dropwise, and the reaction mixture was stirred at rt for 2 days. THF was removed on a rotary evaporator, and the reaction mixture was acidified with $0.5 \mathrm{M} \mathrm{HCl}$ to $\mathrm{pH} 2$, and the product was extracted with ethyl acetate $(3 \times 30 \mathrm{~mL})$. The organic layer was washed with water and dried over anhydrous $\mathrm{Na}_{2} \mathrm{SO}_{4}$. After filtration and evaporation of the solvent, the product was purified by column chromatography on silica gel using $0 \rightarrow 5 \% \mathrm{CH}_{3} \mathrm{OH}$ in $\mathrm{CH}_{2} \mathrm{Cl}_{2}$ as the 
eluent to afford the pure product ( $749 \mathrm{mg}, 57 \%$ ) in a form of a colorless solid.

Colorless solid; mp 92-94 ${ }^{\circ} \mathrm{C} ;{ }^{1} \mathrm{H}$ NMR $\left(\mathrm{CD}_{3} \mathrm{OD}, 300 \mathrm{MHz}\right)$ $\delta / \mathrm{ppm}$ : 7.37-7.27 (m, 5H), 7.25-7.15 (m, 5H), 7.11 (s, 1H), 7.08 (d, $J=8.1 \mathrm{~Hz}, 1 \mathrm{H}), 6.78(\mathrm{~d}, J=8.1 \mathrm{~Hz}, 1 \mathrm{H}), 5.12(\mathrm{~s}, 2 \mathrm{H}), 4.68$ $(\mathrm{ddd}(\mathrm{t}), J=7.0 \mathrm{~Hz}, 1 \mathrm{H}), 4.30-4.22(\mathrm{~m}, 1 \mathrm{H}), 4.13(\mathrm{~s}, 2 \mathrm{H}), 3.09$ $(\mathrm{dd}, J=6.0,14.0 \mathrm{~Hz}, 1 \mathrm{H}), 3.02-2.89(\mathrm{~m}, 2 \mathrm{H}), 2.75(\mathrm{~s}, 6 \mathrm{H})$, 2.75-2.65 (m, 1H), $1.34(\mathrm{~s}, 9 \mathrm{H}) ;{ }^{13} \mathrm{C}$ NMR $\left(\mathrm{CD}_{3} \mathrm{OD}, 75 \mathrm{MHz}\right)$

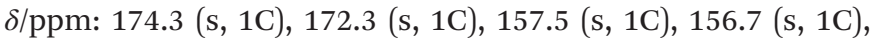
138.5 (s, 1C), 137.0 (s, 1C), 134.1 (d), 133.9 (d), 134.0 (d), 133.0 (d), 129.6 (d), 129.5 (d), 129.4 (d), 129.4 (s), 129.3 (d), 129.2 (d), 127.7 (d), 127.5 (d), 118.2 (s, 1C), 116.4 (d, 1C), 80.6 (s, 1C), 68.0 (t, 1C), 58.3 (t, 1C), 57.1 (d, 1C), 55.3 (d, 1C), 43.2 (q, 2C), 39.3 (t, 1C), 37.1 (t, 1C), 28.6 (q, 3C); HRMS (MALDI-TOF) $\mathrm{m} / \mathrm{z}$ $[\mathrm{M}+\mathrm{H}]^{+}$calcd for $\mathrm{C}_{33} \mathrm{H}_{41} \mathrm{~N}_{3} \mathrm{O}_{6}$ 576.3074, found 576.3087.

\section{BOC-Phe-Tyr[ $\left.\mathrm{CH}_{2} \mathrm{~N}\left(\mathrm{CH}_{3}\right)_{2}\right]-\mathrm{OBn}(2 \mathrm{~B})$}

A flask was charged with BOC-Phe-Tyr-OBn (146 mg, $0.28 \mathrm{mmol})$ dissolved in $\mathrm{CH}_{2} \mathrm{Cl}_{2}(20 \mathrm{~mL})$. To the reaction mixture, $\mathrm{K}_{2} \mathrm{CO}_{3}(20 \mathrm{mg}, 0.14 \mathrm{mmol})$ and Eschenmoser's salt (26 mg, $0.28 \mathrm{mmol}$ ) were added and the reaction was stirred at rt for 5 days. When the reaction was completed, $0.3 \mathrm{M} \mathrm{HCl}$ $(50 \mathrm{~mL})$ was added, and the product was extracted with ethyl acetate $(3 \times 50 \mathrm{~mL})$. The solvent was removed on a rotary evaporator to afford an oily substance which was purified by column chromatography on silica gel using $5 \rightarrow 10 \% \mathrm{CH}_{3} \mathrm{OH}$ in $\mathrm{CH}_{2} \mathrm{Cl}_{2}$ as the eluent to afford the pure product $(50 \mathrm{mg}$, $31 \%$ ) in a form of a colorless solid.

\section{BOC-Phe-Tyr $\left[\mathrm{CH}_{2} \mathrm{~N}\left(\mathrm{CH}_{3}\right)_{2}\right]-\mathrm{OH}(2 \mathrm{~A})$}

In a vessel for hydrogenation BOC-Phe-Tyr $\left[\mathrm{CH}_{2} \mathrm{~N}\left(\mathrm{CH}_{3}\right)_{2}\right]$-OBn (2B) $(263 \mathrm{mg}, 0.4 \mathrm{mmol})$ was dissolved in anhydrous EtOH $(30 \mathrm{~mL})$, and $10 \% \mathrm{Pd} / \mathrm{C}(100 \mathrm{mg})$ was added. Hydrogenation was carried out for $6 \mathrm{~h}$ at the pressure of 63 psi. The crude reaction mixture was filtered and the solvent was removed on a rotary evaporator to afford the pure product ( $221 \mathrm{mg}, 99 \%$ ).

Yellowish oil; ${ }^{1} \mathrm{H}$ NMR $\left(\mathrm{CD}_{3} \mathrm{OD}, 300 \mathrm{MHz}\right) \delta / \mathrm{ppm}: 7.29-7.13$ $(\mathrm{m}, 7 \mathrm{H}), 6.84(\mathrm{~d}, J=8.0 \mathrm{~Hz}, 1 \mathrm{H}), 4.63-4.56(\mathrm{~m}, 1 \mathrm{H}), 4.32-4.18$ (m, 3H), 3.15 (dd, $J=5.0,14.0 \mathrm{~Hz}, 1 \mathrm{H}), 3.04$ (dd, $J=5.0,14.0$ $\mathrm{Hz}, 1 \mathrm{H}), 2.99-2.88(\mathrm{~m}, 1 \mathrm{H}), 2.83(\mathrm{~s}, 6 \mathrm{H}), 2.78-2.69(\mathrm{~m}, 1 \mathrm{H})$, 1.35 (s, 9H); ${ }^{13} \mathrm{C} \mathrm{NMR}\left(\mathrm{CD}_{3} \mathrm{OD}, 150 \mathrm{MHz}\right) \delta / \mathrm{ppm}: 174.6$ (s, 1C), 174.0 (s, 1C), 157.6 (s, 1C), 156.5 (s, 1C), 138.6 (s, 1C), 134.3 (d, 1C), 134.1 (d, 1C), 130.3 (d, 2C), 130.0 (s, 1C), 129.4 (d, 2C), 127.7 (d, 1C), 117.4 (s, 1C), 116.4 (d, 1C), 80.7 (s, 1C), 58.3 (t, 1C), 57.4 (d, 1C), $55.5(\mathrm{~d}, 1 \mathrm{C}), 43.3(\mathrm{q}, 2 \mathrm{C}), 39.2(\mathrm{t}, 1 \mathrm{C}), 37.8$ $(\mathrm{t}, 1 \mathrm{C}), 28.7$ (q, 3C), one singlet was not seen; HRMS (MALDI-TOF) $\mathrm{m} / \mathrm{z}[\mathrm{M}+\mathrm{H}]^{+}$calcd for $\mathrm{C}_{26} \mathrm{H}_{35} \mathrm{~N}_{3} \mathrm{O}_{6}$ 486.2604, found 486.2627 .

\section{BOC-Phe-Tyr $\left[\mathrm{CH}_{2} \mathrm{~N}\left(\mathrm{CH}_{3}\right)_{2}\right]_{2}-\mathrm{OH}(3 \mathrm{~A})$}

To a solution of BOC-Phe-Tyr-OH $(200 \mathrm{mg}, 0.5 \mathrm{mmol})$ in $40 \%$ aqueous dimethylamine $(1 \mathrm{~mL}, 7.8 \mathrm{mmol})$, formalin $(37 \% \mathrm{aq}$, $0.5 \mathrm{~mL}, 6.4 \mathrm{mmol}$ ) was added dropwise and the temperature was maintained below $30^{\circ} \mathrm{C}$ (overall time was $30 \mathrm{~min}$ ). The reaction mixture was stirred at $\mathrm{rt}$ for $1 \mathrm{~h}$, and then at the temperature of $90-95{ }^{\circ} \mathrm{C}$ for $2 \mathrm{~h}$. Then, sodium chloride was added and stirring was continued for $20 \mathrm{~min}$. The resulting oil was subjected to column chromatography on aluminum oxide (act. V) using $5 \rightarrow 10 \% \mathrm{CH}_{3} \mathrm{OH}$ in $\mathrm{CH}_{2} \mathrm{Cl}_{2}$ as the eluent to afford the pure product $(21 \mathrm{mg}, 8 \%)$ in the form of a colorless solid.

Colorless solid; mp $124-126{ }^{\circ} \mathrm{C} ;{ }^{1} \mathrm{H}$ NMR $\left(\mathrm{CD}_{3} \mathrm{OD}\right.$, $300 \mathrm{MHz}) \delta /$ ppm: 7.30-7.15 (m, 5H), $7.04(\mathrm{~s}, 2 \mathrm{H}), 4.39(\mathrm{ddd}(\mathrm{t})$, $J=5.0 \mathrm{~Hz}, 1 \mathrm{H}), 4.27-4.19(\mathrm{~m}, 1 \mathrm{H}), 4.00(\mathrm{~d}, J=13.6 \mathrm{~Hz}, 2 \mathrm{H})$, $3.95(\mathrm{~d}, J=13.6 \mathrm{~Hz}, 2 \mathrm{H}), 3.15-2.95(\mathrm{~m}, 3 \mathrm{H}), 2.80-2.65(\mathrm{~m}, 1 \mathrm{H})$, $2.59(\mathrm{~s}, 12 \mathrm{H}), 1.35(\mathrm{~s}, 9 \mathrm{H}) ;{ }^{13} \mathrm{C}$ NMR $\left(\mathrm{CD}_{3} \mathrm{OD}, 150 \mathrm{MHz}\right) \delta / \mathrm{ppm}$ : 177.2 (s, 1C), 173.3 (s, 1C), 158.6 (s, 1C), 157.5 (s, 1C), 138.8 (s, 1C), 133.3 (d, 1C), 130.3 (d, 2C), 129.8 (s, 1C), 129.4 (d, 2C), 127.7 (d, 2C), $120.2(\mathrm{~s}, 2 \mathrm{C}), 80.4(\mathrm{~s}, 1 \mathrm{C}), 60.4(\mathrm{t}, 2 \mathrm{C}), 57.7$ (d, 1C), $57.4(\mathrm{~d}, 1 \mathrm{C}), 43.8(\mathrm{q}, 4 \mathrm{C}), 39.3(\mathrm{t}, 1 \mathrm{C}), 38.2(\mathrm{t}, 1 \mathrm{C}), 28.7(\mathrm{q}$, 3C); HRMS (MALDI-TOF) $m / z[\mathrm{M}+\mathrm{H}]^{+}$calcd for $\mathrm{C}_{29} \mathrm{H}_{42} \mathrm{~N}_{4} \mathrm{O}_{6}$ 543.3183 , found 543.3177 .

\section{BOC-Phe-Tyr $\left[\mathrm{CH}_{2} \mathrm{~N}\left(\mathrm{CH}_{3}\right)_{2}\right]_{2}-\mathrm{OBn}(3 \mathrm{~B})$}

Prepared from BOC-Phe-Tyr-OBn $(500 \mathrm{mg}, 1.0 \mathrm{mmol})$, dimethylamine ( $40 \%$ aq, $2 \mathrm{~mL}, 3.0 \mathrm{mmol})$, and formalin $(37 \%$ aq, $1 \mathrm{~mL}, 2.5 \mathrm{mmol}$ ), according to the procedure for $3 \mathrm{~A}$. The reaction after purification afforded the product ( $68 \mathrm{mg}, 11 \%$ ) in the form of colorless oil.

Colorless oil; ${ }^{1} \mathrm{H}$ NMR $\left(\mathrm{CD}_{3} \mathrm{OD}, 600 \mathrm{MHz}\right) \delta / \mathrm{ppm}$ : 7.36-7.27 $(\mathrm{m}, 5 \mathrm{H}), 7.25-7.21(\mathrm{~m}, 2 \mathrm{H}), 7.20-7.15(\mathrm{~m}, 3 \mathrm{H}), 6.87(\mathrm{~s}, 2 \mathrm{H})$, $5.10(\mathrm{~s}, 2 \mathrm{H}), 4.68(\mathrm{ddd}(\mathrm{t}), J=7.0 \mathrm{~Hz}, 1 \mathrm{H}), 4.31-4.24(\mathrm{~m}, 1 \mathrm{H})$, $3.55(\mathrm{~d}, J=13.0 \mathrm{~Hz}, 2 \mathrm{H}), 3.51(\mathrm{~d}, J=13.0 \mathrm{~Hz}, 2 \mathrm{H}), 3.06-2.97$ (m, 2H), $2.93(\mathrm{dd}, J=7.5,13.5 \mathrm{~Hz}, 1 \mathrm{H}), 2.73-2.67(\mathrm{~m}, 1 \mathrm{H}), 2.26$ (s, 12H), $1.34(\mathrm{~s}, 9 \mathrm{H}) ;{ }^{13} \mathrm{C}$ NMR $\left(\mathrm{CD}_{3} \mathrm{OD}, 150 \mathrm{MHz}\right) \delta / \mathrm{ppm}:$ 174.1 (s, 1C), 174.0 (s, 1C), 157.2 (s, 1C), 157.1 (s, 1C), 138.5 (s, 1C), 136.9 (s, 1C), 131.6 (d, 2C), 130.4 (d, 2C), 129.6 (d, 1C), 129.4 (d, 2C), 128.2 (d, 1C), 127.9 (d, 1C), 127.8 (s, 1C), 127.7 (d, 2C), $123.4(\mathrm{~s}, 2 \mathrm{C}), 80.6(\mathrm{~s}, 1 \mathrm{C}), 67.9(\mathrm{t}, 1 \mathrm{C}), 60.7(\mathrm{t}, 2 \mathrm{C}), 57.2$ (d, 1C), 55.2 (d, 1C), 44.7 (q, 4C), $39.4(\mathrm{t}, 1 \mathrm{C}), 37.7$ (t, 1C), 28.7 (q, 3C); HRMS (MALDI-TOF) $\mathrm{m} / \mathrm{z}[\mathrm{M}+\mathrm{H}]^{+}$calcd for $\mathrm{C}_{36} \mathrm{H}_{48} \mathrm{~N}_{4} \mathrm{O}_{6} 633.3652$, found 633.3623.

\section{BOC-Asp( ${ }^{t}$ Bu)-Ala-1-OH (4)}

To a solution of the activated Boc-Asp $\left({ }^{t} \mathrm{Bu}\right)-\mathrm{Ala}-\mathrm{OSu}(62.7 \mathrm{mg}$, $137.0 \mu \mathrm{mol})$ in $\mathrm{CH}_{3} \mathrm{CN}(500 \mu \mathrm{L})$, a solution of $\mathrm{NaHCO}_{3}$ (34.5 mg, $3.0 \mathrm{mmol}, 10.0$ eq.) and $\mathbf{1} \cdot \mathrm{HCl}(37.7 \mathrm{mg}, 137.0 \mu \mathrm{mol}$, 1.0 eq.) in $\mathrm{CH}_{3} \mathrm{CN}-\mathrm{H}_{2} \mathrm{O}(1: 2,1.5 \mathrm{~mL})$ was added. The reaction mixture was stirred for $48 \mathrm{~h}$ at $\mathrm{rt}$, before it was diluted with $\mathrm{H}_{2} \mathrm{O}(2 \mathrm{~mL})$ and the $\mathrm{pH}$ was adjusted to 4.0 with $1 \mathrm{M} \mathrm{HCl}$. The aqueous phase was extracted with EtOAc $(3 \times 15 \mathrm{~mL})$. The combined organic phases were washed with $1 \mathrm{M} \mathrm{HCl}(2 \mathrm{~mL})$ and brine $(10 \mathrm{~mL})$, dried over $\mathrm{Na}_{2} \mathrm{SO}_{4}$ and filtered. The solvent was removed under reduced pressure to afford the desired tripeptide 4 (54.5 $\mathrm{mg} \mathrm{67 \% )}$.

${ }^{1} \mathrm{H}$ NMR $\left(\mathrm{CD}_{3} \mathrm{CN}, 500 \mathrm{MHz}\right) \delta / \mathrm{ppm}: 7.23-7.22(\mathrm{~m}, 1 \mathrm{NH})$, $7.16(\mathrm{~s}, 1 \mathrm{H}), 7.11(\mathrm{~d}, J=6.4 \mathrm{~Hz}, 1 \mathrm{H}), 7.02-7.00(\mathrm{~m}, 1 \mathrm{NH}), 6.90$ $(\mathrm{d}, J=8.2 \mathrm{~Hz}, 1 \mathrm{H}), 5.90-5.89(\mathrm{~m}, 1 \mathrm{NH}), 4.54(\mathrm{q}, J=6.7 \mathrm{~Hz}, 1 \mathrm{H})$, $4.34-4.33(\mathrm{~m}, 1 \mathrm{H}), 4.27(\mathrm{t}, J=7.0 \mathrm{~Hz}, 1 \mathrm{H}), 4.21(\mathrm{~s}, 2 \mathrm{H}), 3.07$ $(\mathrm{dd}, J=5.3,14.0 \mathrm{~Hz}, 1 \mathrm{H}), 2.95(\mathrm{dd}, J=6.9,14.0 \mathrm{~Hz}, 1 \mathrm{H}), 2.77$ (s, 6H), $2.68(\mathrm{dd}, J=5.4,16.3 \mathrm{~Hz}, 1 \mathrm{H}), 2.54(\mathrm{dd}, J=7.7,16.3$ $\mathrm{Hz}, 1 \mathrm{H}), 1.41(\mathrm{~s}, 18 \mathrm{H}), 1.24(\mathrm{~d}, J=7.0 \mathrm{~Hz}, 3 \mathrm{H}) ;{ }^{13} \mathrm{C} \mathrm{NMR}$ $\left(\mathrm{CD}_{3} \mathrm{CN}, 126 \mathrm{MHz}\right) \delta / \mathrm{ppm}: 173.0$ (s, 1C), 172.9 (s, 1C), 172.3 (s, 
1C), 171.1 (s, 1C), 155.9 (s, 1C), 134.2 (s, 1C), 133.5 (s, 1C), 129.4 (s, 1C), 129.3 (s, 1C), 117.4 (s, 1C), 116.8 (s, 1C), 82.0 (s, 1C), 80.6 (s, 1C), 57.3 (s, 1C), 54.6 (s, 1C), 52.4 (s, 1C), 49.9 (s, 1C), 43.4 (s, 2C), 38.2 (s, 1C), 36.6 (s, 1C), 28.5 (s, 3C), 28.2 (s, 3C), 18.1 (s, 1C); ESI-MS $[\mathrm{M}+\mathrm{H}]^{+}$calcd for $\mathrm{C}_{28} \mathrm{H}_{45} \mathrm{~N}_{4} \mathrm{O}_{9}$ 581.31811 , found 581.31805 .

\section{General SPPS procedure}

All peptides were synthesized using 2-CT resin via standard Fmoc solid phase peptide synthesis with TBTU and DIPEA as coupling reagents. Manual coupling of canonical amino acids was performed for $40 \mathrm{~min}$ per coupling, with 2.5 equivalents of Fmoc-amino acid and 4.0 equiv. of DIPEA and TBTU. Tripeptide coupling to the resin was performed for $50 \mathrm{~min}$, with 1.0 equiv. of the tripeptide and 3.0 equiv. of DIPEA and TBTU. Deprotection of the Fmoc-group was performed with a $20 \%$ piperidine solution in DMF for $2 \times 15 \mathrm{~min}$. The peptides were deprotected and cleaved from the resin under acidic conditions for $2 \mathrm{~h}$ [84\%TFA/4\% $\mathrm{H}_{2} \mathrm{O} / 4 \%$ phenol/4\% triisopropylsilane/4\% 2,2'-(ethylenedioxy)diethanethiol]. The peptides were then precipitated in cold $\mathrm{Et}_{2} \mathrm{O}$, the supernatant was then decanted and the precipitate was dried under reduced pressure. The purification was achieved using reversed phase HPLC on a 1260 Infinity system (Agilent Technologies) using a $\mathrm{C}_{18}$ preparative column $(21.2 \times 250 \mathrm{~mm}, 10 \mu \mathrm{m}$, Agilent Technologies) with gradients of System B ( $\mathrm{CH}_{3} \mathrm{CN}, 0.1 \%$ TFA) in System A $\left(\mathrm{H}_{2} \mathrm{O}, 0.1 \%\right.$ TFA). The peptides were characterized by electrospray ionization (ESI) mass spectrometry in positive ion mode on an LTQ Orbitrap XL mass spectrometer. A Grace Grom-Sil-120-ODS-4-HE (length $50 \mathrm{~mm}$, ID $2 \mathrm{~mm}, 3 \mu \mathrm{m}$ ) column was used employing a linear gradient of $20-100 \%$ over 10 minutes at $0.3 \mathrm{~mL} \mathrm{m^{-1 }}$. The solvent system used was A ( $0.1 \%$ formic acid in $\left.\mathrm{H}_{2} \mathrm{O}\right)$ and $\mathrm{B}\left(0.1 \%\right.$ formic acid in $\left.\mathrm{CH}_{3} \mathrm{CN}\right)$.

\section{TC10b_3Y1}

The peptide was prepared according to the general procedure from 4 and 17-peptide intermediate bound to the resin. The coupling conditions were: TBTU, DIPEA, DMF, $50 \mathrm{~min}$. The cleavage from the resin was achieved under acidic conditions.

ESI-MS: $(\mathrm{M}+\mathrm{H})^{+}: 2144.06005$.

$m / z=1072.53381(\mathrm{M}+2 \mathrm{H})^{2+}$, calcd for $(\mathrm{M}+2 \mathrm{H})^{2+}$ : 1072.53366 .

$m / z=715.35858(\mathbf{M}+3 \mathrm{H})^{3+}$, calcd for $(\mathbf{M}+3 \mathrm{H})^{3+}:$ 715.35820 .

$m / z=536.77075(\mathrm{M}+4 \mathrm{H})^{4+}$, calcd for $(\mathrm{M}+4 \mathrm{H})^{4+}$ : 536.77047 .

\section{Irradiation experiments, general}

A quartz vessel was filled with a solution of the tyrosine derivative or peptide $(0.1 \mathrm{mmol})$ in $\mathrm{CH}_{3} \mathrm{OH}(50$ or $100 \mathrm{~mL})$. The solution was purged with $\mathrm{Ar}$ (30 $\mathrm{min})$ and irradiated using a Rayonet reactor at $300 \mathrm{~nm}$ with 11 lamps over 30-90 min (1 lamp, $8 \mathrm{~W}$ ). During irradiation, the solution was continuously purged with Ar and cooled with a finger condenser. The composition of the irradiated solution was analyzed by HPLC. After the irradiation, the solvent was removed on a rotary evaporator and the residue was purified by chromatography.

\section{Irradiation of 1B}

Irradiation of $1 \mathrm{~B}(54 \mathrm{mg}, 0.12 \mathrm{mmol})$ in $\mathrm{CH}_{3} \mathrm{OH}(100 \mathrm{~mL})$ for 40 min after purification by TLC using $10 \% \mathrm{CH}_{3} \mathrm{OH}$ in $\mathrm{CH}_{2} \mathrm{Cl}_{2}$ as the eluent afforded the pure product 6 (14 $\mathrm{mg}, 28 \%)$.

Colorless oil; ${ }^{1} \mathrm{H}$ NMR $\left(\mathrm{CD}_{3} \mathrm{OD}, 300 \mathrm{MHz}\right) \delta / \mathrm{ppm}$ : 7.38-7.26 $(\mathrm{m}, 6 \mathrm{H}), 6.86(\mathrm{~d}, J=8.4 \mathrm{~Hz}, 1 \mathrm{H}), 6.74(\mathrm{~d}, J=8.4 \mathrm{~Hz}, 1 \mathrm{H}), 6.68$ (s, 1H), 5.17 (d, $J=12.6 \mathrm{~Hz}, 1 \mathrm{H}), 5.08$ (d, $J=12.6 \mathrm{~Hz}, 1 \mathrm{H}), 4.96$ (d, $J=7.6 \mathrm{~Hz}, 1 \mathrm{H}), 4.60-4.45(\mathrm{~m}, 3 \mathrm{H}), 3.40(\mathrm{~s}, 3 \mathrm{H}), 3.05-2.89$ $(\mathrm{m}, 2 \mathrm{H}), 1.41(\mathrm{~s}, 9 \mathrm{H}) ;{ }^{13} \mathrm{C} \mathrm{NMR}\left(\mathrm{CD}_{3} \mathrm{OD}, 150 \mathrm{MHz}\right) \delta / \mathrm{ppm}$ : 171.8 (s, 1C), 155.5 (s, 1C), 155.1 (s, 1C), 135.3 (s, 1C), 130.3 (d, 1C), 128.9 (d, 2C), 128.6 (d, 1C), 128.5 (d, 2C), 127.9 (s, 1C), 127.0 (s, 1C), 122.0 (d, 1C), 116.6 (d, 1C), 79.9 (s, 1C), $74.0(\mathrm{t}$, 1C), 67.0 (t, 1C), 58.2 (q, 1C), 54.6 (d, 1C), $37.4(\mathrm{t}, 1 \mathrm{C}), 28.7$ (q, $3 \mathrm{C}$ ); HRMS (MALDI-TOF) $\mathrm{m} / z \quad[\mathrm{M}]^{+}$calcd for $\mathrm{C}_{23} \mathrm{H}_{29} \mathrm{NO}_{6}$ 415.2073, found 415.2094.

\section{Irradiation of $2 \mathrm{~B}$}

Irradiation of $2 \mathbf{B}(62 \mathrm{mg}, 0.11 \mathrm{mmol})$ in $\mathrm{CH}_{3} \mathrm{OH}(100 \mathrm{~mL})$ for 30 min after purification by TLC using $10 \% \mathrm{CH}_{3} \mathrm{OH}$ in $\mathrm{CH}_{2} \mathrm{Cl}_{2}$ as the eluent afforded the pure product 7 (13 $\mathrm{mg}, 21 \%)$.

Colorless oil; ${ }^{1} \mathrm{H}$ NMR $\left(\mathrm{CD}_{3} \mathrm{OD}, 600 \mathrm{MHz}\right) \delta / \mathrm{ppm}$ : 7.38-7.33 (m, 3H), 7.30-7.24 (m, 5H), 7.24-7.18 (m, 1H), 7.17 (d, $J=7.0$ $\mathrm{Hz}, 2 \mathrm{H}), 6.70-6.65$ (m, 2H), 6.59 (s, 1H), 6.28 (br. s), 5.10 (d, $J=$ $12.0 \mathrm{~Hz}, 1 \mathrm{H}$ ), 5.07 (d, $J=12.0 \mathrm{~Hz}, 1 \mathrm{H}$ ), 4.97 (br. s), 4.77-4.73 (m, 1H), 4.49 (d, J = 12.5 Hz, 1H), 4.46 (d, J = 12.5 Hz, 1H), 4.32 (br. s), 3.38 (s, 3H), 3.02 (d, J=6 Hz, 2H), 2.94 (d, $J=6 \mathrm{~Hz}, 2 \mathrm{H})$, 1.34 (s, 9H); ${ }^{13} \mathrm{C}$ NMR (CD $\left.30 D, 150 \mathrm{MHz}\right) \delta / \mathrm{ppm}: 170.8(\mathrm{~s})$, 170.7 (s), 155.2 (s), 136.5 (s), 135.0 (s), 130.2 (d), 129.4 (d), 129.0 (d), 128.7 (d), 128.6 (s), 128.54 (d), 128.51 (d), 126.9 (d), $126.6(\mathrm{~s}), 122.1(\mathrm{~s}), 116.5(\mathrm{~d}), 80.2(\mathrm{~s}), 73.8(\mathrm{t}), 67.1(\mathrm{t}), 58.2(\mathrm{q})$, $55.7(\mathrm{~d}), 53.4(\mathrm{~d}), 38.3(\mathrm{t}), 37.0(\mathrm{t}), 28.2(\mathrm{q})$, one singlet was not seen; HRMS (MALDI-TOF) $m / z[\mathrm{M}+\mathrm{K}]^{+}$calcd for $\mathrm{C}_{32} \mathrm{H}_{38} \mathrm{~N}_{2} \mathrm{O}_{7}$ 601.2316 , found 601.2328 .

\section{Irradiation of 3B}

Irradiation of $3 \mathbf{B}(28 \mathrm{mg}, 0.04 \mathrm{mmol})$ in $\mathrm{CH}_{3} \mathrm{OH}(50 \mathrm{~mL})$ for $30 \mathrm{~min}$ after purification by TLC using $10 \% \mathrm{CH}_{3} \mathrm{OH}$ in $\mathrm{CH}_{2} \mathrm{Cl}_{2}$ as the eluent afforded the pure product 9 ( $5 \mathrm{mg}, 21 \%)$.

Colorless oil; ${ }^{1} \mathrm{H}$ NMR $\left(\mathrm{CD}_{3} \mathrm{OD}, 300 \mathrm{MHz}\right) \delta / \mathrm{ppm}$ : 7.38-7.33 $(\mathrm{m}, 5 \mathrm{H}), 7.31-7.27(\mathrm{~m}, 2 \mathrm{H}), 7.25-7.21(\mathrm{~m}, 2 \mathrm{H}), 7.21-7.15(\mathrm{~m}$, $5 \mathrm{H}), 6.71(\mathrm{~s}, 2 \mathrm{H}), 5.11-5.08(\mathrm{~s}, 2 \mathrm{H}), 4.81-4.73(\mathrm{~m}, 1 \mathrm{H}), 4.46(\mathrm{~s}$, $4 \mathrm{H}), 4.39-4.28(\mathrm{~m}, 1 \mathrm{H}), 3.42-3.36 \mathrm{~m}, 6 \mathrm{H}), 3.13-2.88(\mathrm{~m}, 4 \mathrm{H})$, 1.37 (s, 9H); ${ }^{13} \mathrm{C}$ NMR (CD $\left.3 \mathrm{OD}, 150 \mathrm{MHz}\right) \delta / \mathrm{ppm}: 170.8(\mathrm{~s})$, 153.1 (s), 136.8 (s), 135.1 (s), 129.4 (d), 129.1 (d), 128.64 (d), 128.60 (d), 128.5 (d), 128.4 (d), 126.9 (d), 126.4 (s), 123.6 (s), $80.5(\mathrm{~s}), 71.6(\mathrm{t}), 67.1(\mathrm{t}), 58.3(\mathrm{q}), 53.5(\mathrm{~d}), 53.4(\mathrm{~d}), 38.2(\mathrm{t})$, 37.1 (t), 28.7 (q), two singlets were not seen; HRMS (MALDI-TOF) $m / z[\mathrm{M}+\mathrm{K}]^{+}$calcd for $\mathrm{C}_{34} \mathrm{H}_{42} \mathrm{~N}_{2} \mathrm{O}_{8}$ 645.2578, found 645.2570 . 


\section{Irradiation of $3 \mathrm{~A}$}

Irradiation of $3 \mathbf{A}(59 \mathrm{mg}, 0.11 \mathrm{mmol})$ in $\mathrm{CH}_{3} \mathrm{OH}(100 \mathrm{~mL})$ for 75 min after purification by TLC using $10 \% \mathrm{CH}_{3} \mathrm{OH}$ in $\mathrm{CH}_{2} \mathrm{Cl}_{2}$ as the eluent afforded the pure product 10 (5 mg, 9\%).

Colorless oil; ${ }^{1} \mathrm{H}$ NMR (CD $\left.{ }_{3} \mathrm{OD}, 300 \mathrm{MHz}\right) \delta / \mathrm{ppm}$ : 7.30-7.15 $(\mathrm{m}, 5 \mathrm{H}), 7.04(\mathrm{~s}, 2 \mathrm{H}), 6.94-6.84(\mathrm{~m}, 1 \mathrm{H}), 4.68-4.57(\mathrm{~m}, 1 \mathrm{H})$, 4.54-4.50 (m, 4H), 4.31-4.24 (m, 1H), 3.38 (s, 6H), 3.19-2.98 $(\mathrm{m}, 2 \mathrm{H}), 2.76-2.63(\mathrm{~m}, 2 \mathrm{H}), 1.33(\mathrm{~s}, 9 \mathrm{H}) ;{ }^{13} \mathrm{C} \mathrm{NMR}\left(\mathrm{CD}_{3} \mathrm{OD}\right.$, $150 \mathrm{MHz}) \delta / \mathrm{ppm}: 174.0$ (s, 1C), 157.5 (s, 1C), 154.0 (s, 1C), 138.7 (s, 1C), 131.2 (d, 1C), 130.3 (d, 2C), 129.4 (d, 2C), 129.0 (s, 1C), 127.6 (d, 1C), $125.4(\mathrm{~s}, 2 \mathrm{C}), 80.7$ (s, 1C), $72.0(\mathrm{t}, 2 \mathrm{C})$, 58.5 (q, 2C), 57.5 (d, 1C), 55.3 (d, 1C), $39.2(\mathrm{t}, 1 \mathrm{C}), 37.6(\mathrm{t}, 1 \mathrm{C})$, 28.6 (q, 3C), one singlet was not seen; HRMS (MALDI-TOF) $\mathrm{m} / \mathrm{z}$ $[\mathrm{M}+\mathrm{K}]^{+}$calcd for $\mathrm{C}_{27} \mathrm{H}_{36} \mathrm{~N}_{2} \mathrm{O}_{8}$ 555.2109, found 555.2083.

\section{Quantum yield of methanolysis}

Quantum yields for photomethanolysis reactions were determined by using two actinometers simultaneously: $\mathrm{KI} / \mathrm{KIO}_{3}$ $\left(\Phi_{254}=0.74\right),{ }^{47,51}$ and photomethanolysis of 2-hydroxymethylphenol $\left(\Phi_{254}=0.23\right),{ }^{28}$ as recently described by us. ${ }^{71}$ The measurement was performed in eight quartz cells of the same dimensions that were irradiated from the front side only. Solutions of tyrosines or peptide derivatives in $\mathrm{CH}_{3} \mathrm{OH}$, and actinometers were freshly prepared and their concentrations were adjusted to have absorbances of $0.4-0.8$ at $254 \mathrm{~nm}$. After adjustment of the concentrations and measurement of the corresponding UV-vis spectra, the solutions were purged with a stream of $\mathrm{N}_{2}(20 \mathrm{~min})$, and then sealed with a cap. The cells were placed in a holder which ensured an equal distance of all samples from the lamp and were irradiated at the same time in the reactor with 1 lamp at $254 \mathrm{~nm}$ for 1-15 min. Before and after the irradiation, the samples were taken from the cells by the use of a syringe and analyzed by HPLC to determine photochemical conversions. The conversion did not exceed 30\% to avoid a change of the absorbance, or filtering of the light by the product. From the conversion of actinometers irradiance was calculated. Similar values were obtained for both actinometers. The mean value of two measurements was reported. All equations for the calculation of quantum yields are given in the ESI. $\dagger$

\section{Steady-state and time-resolved fluorescence measurements}

The steady-state measurements were performed on a PTI QM40 fluorometer at $20{ }^{\circ} \mathrm{C}$. Excitation slits were set to a bandpass of $3 \mathrm{~nm}$, and emission slits to a bandpass of $2 \mathrm{~nm}$. The spectra were corrected for the fluctuations in lamp intensity and transmission of optics. The samples were dissolved in $\mathrm{CH}_{3} \mathrm{CN}$, or $\mathrm{CH}_{3} \mathrm{CN}-\mathrm{H}_{2} \mathrm{O}(1: 1)$ and the concentrations were adjusted to absorbances less than 0.1 at the excitation wavelengths of 250, 260 or $270 \mathrm{~nm}$. Fluorescence quantum yields were determined by comparison of the integral of the emission bands with the one of anisole in cyclohexane $\left(\Phi_{\mathrm{f}}=0.29\right)^{47}$ upon excitation at $260 \mathrm{~nm}$. The quantum yields were calculated according to eqn (S1) in the ESI. $\dagger$ Fluorescence decays, collected over 1023 time channels, were obtained on a single photon counter using a light emitting diode for excitation at $260 \mathrm{~nm}$. The instrument response functions, using LUDOX as the scatterer, were recorded at the same wavelengths as the excitation wavelength and had a half width of $\approx 0.2$ ns. Emission decays for samples in $\mathrm{CH}_{3} \mathrm{CN}$ solutions were recorded at $310 \mathrm{~nm}$. The counts in the peak channel were $1 \times 10^{3}$. The time increment per channel was $0.020 \mathrm{~ns}$. The obtained histograms were fit as sums of exponentials using Gaussian-weighted non-linear least-squares fitting based on Marquardt-Levenberg minimization implemented in the software package from the instrument. The fitting parameters (decay times and pre-exponential factors) were determined by minimizing the reduced chi-square $\chi^{2}$ and graphical methods were used to judge the quality of the fit that included plots of the weighted residuals $v s$. channel number.

\section{Laser flash photolysis (LFP)}

All LFP studies were performed on a system at the University of Victoria $^{72}$ using as an excitation source a pulsed Nd:YAG laser at $266 \mathrm{~nm}(<20 \mathrm{~mJ}$ per pulse), with a pulse width of $10 \mathrm{~ns}$. Static cells $(7 \mathrm{~mm} \times 7 \mathrm{~mm})$ were used and the solutions were purged with nitrogen or oxygen for $30 \mathrm{~min}$ prior to perform the measurements. Absorbances at $266 \mathrm{~nm}$ were $\sim 0.3-0.5$. For the collection of decays on long time scales, a modification of the setup was used, wherein the probing light beam from the Xe-lamp was not pulsed. ${ }^{73}$

\section{Acknowledgements}

These materials are based on work financed by the ESF project HR.3.2.01-0254 and the Croatian Science Foundation (HRZZ grant IP-2014-09-6312). The authors thank the Department of Chemistry at the University of Victoria, Canada and Prof. P. Wan and C. Bohne for the support and the use of LFP facilities.

\section{Notes and references}

1 Quinone Methides, ed. S. E. Rokita, Wiley, Hoboken, 2009.

2 M. S. Singh, A. Nagaraju, N. Anand and S. Chowdhury, RSC Adv., 2014, 4, 55924-55959.

3 R. W. Van De Water and T. R. R. Pettus, Tetrahedron, 2002, 58, 5367-5405.

4 T. P. Pathak and M. S. Sigman, J. Org. Chem., 2011, 76, 9210-9215.

5 M. Frecero, Mini-Rev. Org. Chem., 2004, 1, 403-415.

6 P. Wang, Y. Song, L. Zhang, H. He and X. Zhou, Curr. Med. Chem., 2005, 12, 2893-2913.

7 N. Basarić, K. Mlinarić-Majerski and M. Kralj, Curr. Org. Chem., 2014, 18, 3-18.

8 S. E. Rokita, J. Yang, P. Pande and W. A. Greenberg, J. Org. Chem., 1997, 62, 3010-3012.

9 W. F. Veldhuyzen, A. J. Shallop, R. A. Jones and S. E. Rokita, J. Am. Chem. Soc., 2001, 123, 11126-11132. 
10 E. E. Weinert, K. N. Frankenfield and S. E. Rokita, Chem. Res. Toxicol., 2005, 18, 1364-1370.

11 M. Chatterjee and S. E. Rokita, J. Am. Chem. Soc., 1994, 116, 1690-1697.

12 Q. Zeng and S. E. Rokita, J. Org. Chem., 1996, 61, 90809081.

13 P. Pande, J. Shearer, J. Yang, W. A. Greenberg and S. E. Rokita, J. Am. Chem. Soc., 1999, 121, 6773-6779.

14 W. F. Veldhuyzen, P. Pande and S. E. Rokita, J. Am. Chem. Soc., 2003, 125, 14005-14013.

15 S. N. Richter, S. Maggi, S. Colloredo Mels, M. Palumbo and M. Freccero, J. Am. Chem. Soc., 2004, 126, 13973-13979.

16 H. Wang, Curr. Org. Chem., 2014, 18, 44-60.

17 H. Wang, M. S. Wahi and S. E. Rokita, Angew. Chem., Int. Ed., 2008, 47, 1291-1293.

18 H. Wang and S. E. Rokita, Angew. Chem., Int. Ed., 2010, 49, 5957-5960.

19 C. S. Rossiter, E. Modica, D. Kumar and S. E. Rokita, Chem. Commun., 2011, 47, 1476-1478.

20 P. G. McCracken, J. L. Bolton and G. R. J. Thatcher, J. Org. Chem., 1997, 62, 1820-1825.

21 E. Modica, R. Zanaletti, M. Freccero and M. Mella, J. Org. Chem., 2001, 66, 41-52.

22 S. Arumugam, J. Guo, N. E. Mbua, F. Friscourt, N. Lin, E. Nekongo, G.-J. Boons and V. V. Popik, Chem. Sci., 2014, 5, 1591-1598.

23 M. Kralj, L. Uzelac, Y.-H. Wang, P. Wan, M. Tireli, K. Mlinarić-Majerski, I. Piantanida and N. Basarić, Photochem. Photobiol. Sci., 2015, 14, 1082-1092.

24 G. G.-H. Qiao, K. Lenghaus, D. H. Solomon, A. Reisinger, I. Bytheway and C. Wentrup, J. Org. Chem., 1998, 63, 98069811.

25 E. Dorrestijn, M. Kranenburg, M. V. Ciriano and P. Mulder, J. Org. Chem., 1999, 64, 3012-3018.

26 D. A. Bolon, J. Org. Chem., 1970, 35, 3666-3670.

27 C. Percivalle, F. Doria and M. Freccero, Curr. Org. Chem., 2014, 18, 19-43.

28 L. Diao, C. Yang and P. Wan, J. Am. Chem. Soc., 1995, 117, 5369-5370.

29 B. Baker, L. Diao and P. Wan, J. Photochem. Photobiol., A, 1997, 104, 91-96.

30 K. Nakatani, N. Higashida and I. Saito, Tetrahedron Lett., 1997, 38, 5005-5008.

31 S. Colloredo-Mels, F. Doria, D. Verga and M. Freccero, J. Org. Chem., 2006, 71, 3889-3895.

32 M. Di Antonio, F. Doria, M. Mella, D. Merli, A. Profumo and M. Freccero, J. Org. Chem., 2007, 72, 8354-8360.

33 D. Verga, M. Nadai, F. Doria, C. Percivalle, M. Di Antonio, M. Palumbo, S. N. Richter and M. Freccero, J. Am. Chem. Soc., 2010, 132, 14625-14637.

34 F. Doria, S. N. Richter, M. Nadai, S. Colloredo-Mels, M. Mella, M. Palumbo and M. Freccero, J. Med. Chem., 2007, 50, 6570-6579.

35 M. Nadai, F. Doria, M. Di Antonio, G. Sattin, L. Germani, C. Percivalle, M. Palumbo, S. N. Richter and M. Freccero, Biochimie, 2011, 93, 1328-1340.
36 F. Doria, M. Nadai, M. Folini, M. Di Antonio, L. Germani, C. Percivalle, C. Sissi, N. Zaffaroni, S. Alcaro, A. Artese, S. N. Richter and M. Freccero, Org. Biomol. Chem., 2012, 10, 2798-2806.

37 F. Doria, M. Nadai, M. Folini, M. Scalabrin, L. Germani, G. Sattin, M. Mella, M. Palumbo, N. Zaffaroni, D. Fabris, M. Freccero and S. N. Richter, Chem. - Eur. J., 2013, 19, 78-81.

38 Đ. Škalamera, C. Bohne, S. Landgraf and N. Basarić, J. Org. Chem., 2015, 80, 10817-10828.

39 F. Doria, A. Lena, R. Bargiggia and M. Freccero, J. Org. Chem., 2016, 81, 3665-3673.

40 B. Barua, J. C. Lin, W. D. Williams, P. Kummler, J. W. Neidigh and N. H. Andersen, Protein Eng., Des. Sel., 2008, 21, 171-185.

41 J. W. Neidigh, R. M. Fesinmeyer and N. H. Andersen, Nat. Struct. Biol., 2002, 9, 425-430.

42 L. Qiu, S. A. Pabit, A. E. Roitberg and S. J. Hagen, J. Am. Chem. Soc., 2002, 124, 12952-12953.

43 B. P. Noichl, P. M. Durkin and N. Budiša, Biopolymers, 2015, 104, 585-600.

44 Synthesis of Peptides and Peptidomimetics, ed. A. Felix, L. Moroder and C. Toniolo, Thieme, Stuttgart, 2004, vol. 22 .

45 B. Siddique and J. Duhamel, Langmuir, 2011, 27, 66396650.

46 V. Dourtoglov and B. Gross, Synthesis, 1984, 572-575.

47 M. Montalti, A. Credi, L. Prodi and M. T. Gandolfi, in Handbook of Photochemistry, CRC Taylor and Francis, Boca Raton, 2006.

48 J. F. Ireland and P. A. H. Wyatt, Adv. Phys. Org. Chem., 1976, 12, 131-221.

49 L. G. Arnaut and S. J. Formosinho, J. Photochem. Photobiol., A, 1993, 75, 1-20.

50 E. E. Weinert, R. Dondi, S. Colloredo-Melz, K. N. Frankenfield, C. H. Mitchell, M. Freccero and S. E. Rokita, J. Am. Chem. Soc., 2006, 128, 11940-11947.

51 S. Goldstein and J. Rabani, J. Photochem. Photobiol., 2008, 193, 50-55.

52 J. Lee, G. W. Robinson, S. P. Webb, L. A. Philips and J. H. Clark, J. Am. Chem. Soc., 1986, 108, 6538-6542.

53 G. W. Robinson, J. Phys. Chem., 1991, 95, 10386-10391.

54 L. M. Tolbert and J. E. Haubrich, J. Am. Chem. Soc., 1994, 116, 10593-10600.

55 K. M. Solntsev, D. Huppert, N. Agmon and L. M. Tolbert, J. Phys. Chem. A, 2000, 104, 4658-4669.

56 Y. Chiang, A. J. Kresge and Y. Zhu, J. Am. Chem. Soc., 2000, 122, 9854-9855.

57 Y. Chiang, A. J. Kresge and Y. Zhu, J. Am. Chem. Soc., 2001, 123, 8089-8094.

58 Y. Chiang, A. J. Kresge and Y. Zhu, J. Am. Chem. Soc., 2002, 124, 717-722.

59 M. M. Toteva and J. P. Richard, Adv. Phys. Org. Chem., 2011, 45, 39-91.

60 S. Arumugam and V. V. Popik, J. Am. Chem. Soc., 2009, 131, 11892-11899. 
61 N. Basarić, I. Žabčić, K. Mlinarić-Majerski and P. Wan, J. Org. Chem., 2010, 75, 102-116.

62 D. Brousmiche, M. Xu, M. Lukeman and P. Wan, J. Am. Chem. Soc., 2003, 125, 12961-12970.

$63 \mathrm{M} . \mathrm{Xu}, \mathrm{M}$. Lukeman and P. Wan, Photochem. Photobiol., 2006, 82, 50-56.

64 N. Basarić, N. Cindro, D. Bobinac, K. Mlinarić-Majerski, L. Uzelac, M. Kralj and P. Wan, Photochem. Photobiol. Sci., 2011, 10, 1910-1925.

65 N. Basarić, N. Cindro, D. Bobinac, K. Mlinarić-Majerski, L. Uzelac, M. Kralj and P. Wan, Photochem. Photobiol. Sci., 2012, 11, 381-396.

66 J. Veljković, L. Uzelac, K. Molčanov, K. Mlinarić-Majerski, M. Kralj, P. Wan and N. Basarić, J. Org. Chem., 2012, 77, 4596-4610.
67 S. Arumugam and V. V. Popik, J. Am. Chem. Soc., 2011, 133, 5573-5579.

68 O. Keller, W. E. Keller, G. van Look and G. Wersin, Org. Synth., 1990, 7, 70-78.

69 J. R. Luly, N. Yi, J. Soderquist, H. Stein, J. Cohen, T. J. Perun and J. J. Plattner, J. Med. Chem., 1987, 30, 16091616.

70 S. Liaqat, S. S. Panda, A. Rauf, A. O. Al-Youbi and A. Katritzky, Synthesis, 2014, 67-72.

71 Đ. Škalamera, K. Mlinarić-Majerski, I. Martin-Kleiner, M. Kralj, P. Wan and N. Basarić, J. Org. Chem., 2014, 79, 4390-4397.

72 Y. Liao and C. Bohne, J. Phys. Chem., 1996, 100, 734-743.

73 R. H. Mitchell, C. Bohne, Y. Wang, S. Bandyopadhyay and C. B. Wozniak, J. Org. Chem., 2006, 71, 327-336. 